\title{
Bureau of Justice Statistics
} Special Report

\section{Parents i
Children \\ Lauren E. Glaze \\ and Laura M. Maruschak \\ BJS Statisticians}

An estimated 809,800 prisoners of the $1,518,535$ held in the nation's prisons at midyear 2007 were parents of minor children, or children under age 18. Parents held in the nation's prisons $-52 \%$ of state inmates and $63 \%$ of federal inmates-reported having an estimated $1,706,600$ minor children, accounting for $2.3 \%$ of the U.S. resident population under age 18. Unless otherwise specified in this report, the word parent refers to state and federal prisoners who reported having minor children. The word children refers to youth under age 18.

Between 1991 and midyear 2007, parents held in state and federal prisons increased by $79 \%$ (357,300 parents). Children of incarcerated parents increased by $80 \%(761,000$ children), during this period (figure 1). The most rapid growth in the number of parents held in the nation's prisons and their children occurred between 1991 and 1997 (both up 44\%). From 1997 to midyear 2007, the number of parents and children continued to grow, but at a slower pace (both up 25\%).

The findings in this report are based on the latest data collected through personal interviews with prisoners participating in the Bureau of Justice Statistics' (BJS) 2004 Survey of Inmates in State and Federal Correctional Facilities (SISFCF), which is comprised of two separate surveys.

One survey is conducted in state adult correctional facilities and the other is conducted in federal correctional facilities. Estimates presented in this report may not be comparable to previously published reports. See Incarcerated Parents and Their Minor Children at <http://www.ojp.usdoj.gov/bjs/ abstract/iptc.htm>.

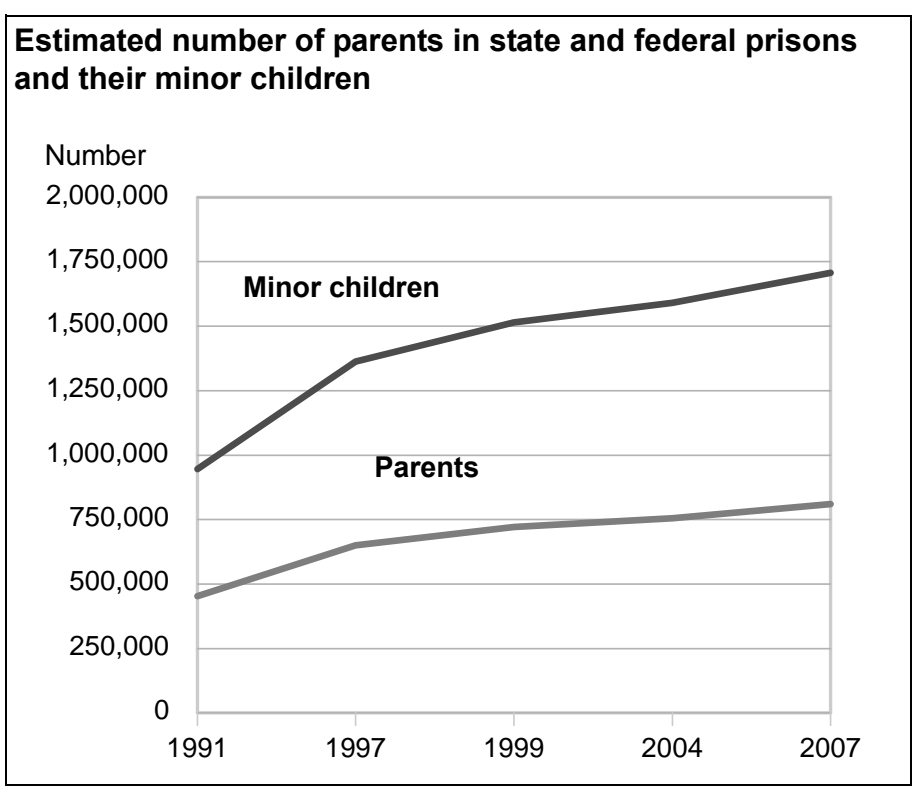

Figure 1

\section{Parents of minor children held in the nation's prisons increased by $79 \%$ between 1991 and midyear 2007}

Growth in the number of parents held in state and federal prisons was outpaced by the growth in the nation's prison population between 1991 and midyear 2007. Parents incarcerated in state and federal prisons increased by $79 \%$ during this period while the custody population grew by $92 \%$.

Detailed information is available in appendix tables in the online version of this report on the BJS Website at <http://www.ojp.usdoj.gov/bjs/pub/ pdf/pptmc.pdf>. 
Parents held in state prison increased from 413,100 in 1991 to 686,000 at midyear 2007 (table 1). Children of parents in state prison increased from 860,300 to $1,427,500$ during this period. The largest growth in the number of parents (up 40\%) held in state prison and their children (up 42\%) occurred between 1991 and 1997, compared to a $19 \%$ increase for parents and a $17 \%$ increase for their children between 1997 and midyear 2007.

\section{The number of children under age 18 with a mother in prison more than doubled since 1991}

The nation's prisons held approximately 744,200 fathers and 65,600 mothers at midyear 2007 (appendix table 1). Fathers in prison reported having 1,559,200 children; mothers reported 147,400 .

Since 1991, the number of children with a mother in prison has more than doubled, up 131\%. The number of children with a father in prison has grown by $77 \%$. This finding reflects a faster rate of growth in the number of mothers held in state and federal prisons (up 122\%), compared to the number of fathers (up 76\%) between 1991 and midyear 2007.

Of the estimated 74 million children in the U.S. resident population who were under age 18 on July 1, 2007, 2.3\% had a parent in prison (table 2). Black children (6.7\%) were seven and a half times more likely than white children $(0.9 \%)$ to have a parent in prison. Hispanic children $(2.4 \%)$ were more than two and a half times more likely than white children to have a parent in prison.

Table 1. Estimated number of parents in state and federal prisons and their minor children

\begin{tabular}{lrrr} 
& Total & State & Federal $^{\mathrm{a}}$ \\
\hline Number of parents & & & \\
$2007^{\mathrm{b}}$ & 809,800 & 686,000 & 123,800 \\
$2004^{\mathrm{c}}$ & 754,900 & 644,100 & 110,800 \\
1999 & 721,500 & 642,300 & 79,200 \\
1997 & 649,500 & 578,100 & 62,500 \\
1991 & 452,500 & 413,100 & 39,400 \\
Number of children & & & \\
$2007^{\mathrm{b}}$ & $1,706,600$ & $1,427,500$ & 279,100 \\
$2004^{\mathrm{c}}$ & $1,590,100$ & $1,340,300$ & 249,800 \\
$1999^{\mathrm{d}}$ & $1,515,200$ & $1,338,900$ & 176,300 \\
$1997^{\mathrm{d}}$ & $1,362,900$ & $1,223,800$ & 139,100 \\
$1991^{\mathrm{d}}$ & 945,600 & 860,300 & 85,100 \\
\hline
\end{tabular}

Note: See Methodology for details about estimation methods. See appendix table 1 for estimates by gender.

${ }^{a}$ Estimates were based on the prisoner custody population in each year. The total custody population included inmates held in privately operated facilities and community corrections centers $(30,379$ in 2007 ; 24,768 in 2004; and 3,828 inmates in privately operated facilities in 1999). In 1991 and 1997, the number of inmates in these facilities was not known.

${ }^{b}$ The 2007 estimates were based on the distribution of parents from the 2004 SISFCF.

${ }^{\mathrm{C}}$ Numbers were estimated based on the custody population in state $(1,241,034)$ and federal $(176,156)$ prisons on June 30, 2004.

dEstimates may not be comparable to previously published BJS reports.
More than 4 in 10 fathers in state or federal prisons were black; almost 5 in 10 mothers were white

Similar to men in the general prison population (93\%), parents held in the nation's prisons at midyear 2007 were mostly male (92\%) (not shown in table). More than 4 in 10 fathers were black, about 3 in 10 were white, and about 2 in 10 were Hispanic (appendix table 2). An estimated $1,559,200$ children had a father in prison at midyear 2007; nearly half (46\%) were children of black fathers.

Almost half (48\%) of all mothers held in the nation's prisons at midyear 2007 were white, $28 \%$ were black, and $17 \%$ were Hispanic. Of the estimated 147,400 children with a mother in prison, about $45 \%$ had a white mother. A smaller percentage of the children had a black $(30 \%)$ or Hispanic (19\%) mother.

\section{The majority of prisoners reported having a minor child, a quarter of which were age 4 or younger}

When interviewed during the 2004 survey, the majority of state (52\%) and federal (63\%) inmates reported having at least one child under age 18 (appendix table 3). Women in state prison (62\%) were more likely than men (51\%) to report being a parent. Among federal inmates, $63 \%$ of male inmates and $56 \%$ of female inmates reported being a parent.

Nearly 1 in 4 state (23\%) and federal (24\%) inmates reported having one child. Federal inmates (39\%) were more likely than state inmates $(29 \%)$ to report having multiple children. Women (41\%) in state prison were more likely than men (29\%) to report having more than one child. Similar percentages of women (36\%) and men (39\%) held in federal prison reported having multiple children. Parents in state and federal prisons reported having two children, on average (not shown in table).

Table 2. Minor children in the U.S. resident population with a parent in state or federal prison, by race and Hispanic origin, 2007

\begin{tabular}{lcc} 
& $\begin{array}{c}\text { Estimated number of } \\
\text { minor children with a } \\
\text { parent in prison }\end{array}$ & $\begin{array}{l}\text { Percent of all minor } \\
\text { children in the U.S. } \\
\text { resident population }\end{array}$ \\
\hline \multicolumn{1}{c}{ U.S. total } & $1,706,600$ & $2.3 \%$ \\
White, non-Hispanic & 484,100 & $0.9 \%$ \\
Black, non-Hispanic & 767,400 & 6.7 \\
Hispanic & 362,800 & 2.4
\end{tabular}

Note: Children were assumed to have the same race/ethnicity as the incarcerated parent. Percentages were calculated based on the U.S. resident population under age 18 as of July 1, 2007.

*Includes children of other races. Other races include American Indians, Alaska Natives, Asians, Native Hawaiians, other Pacific Islanders, and persons identifying two or more races. 
Twenty-two percent of the children of state inmates and $16 \%$ of the children of federal inmates were age 4 or younger (table 3). For both state (53\%) and federal (50\%) inmates, about half their children were age 9 or younger. Children of female state inmates were slightly older than children reported by male state inmates. More than half (53\%) of the children reported by women were between age 10 and 17 , compared to $47 \%$ of the children reported by men.

\section{More than a third of minor children will reach age 18 while their parent is incarcerated}

Based on the number of adult children reported during the 2004 survey, the total number of children affected by an incarcerated parent can be calculated by subtracting the amount of time served by the parent from their adult child's age. Using this method, parents in prison had nearly 1.9 million children at the time of admission (table 4). Of those children, an estimated 715,600 will reach age 18 while their parent is incarcerated.

\section{Incarcerated parents of minor children most likely to be age 25 to 34}

State inmates age 25 to 34 (64\%) interviewed during the 2004 survey were most likely to be parents of minor children, followed by inmates age 35 to 44 and inmates age 24 or younger (table 5). Thirty-one percent of inmates age 45

Table 3. Percent of minor children of parents in state and federal prisons at time of interview, by gender, 2004

\begin{tabular}{|c|c|c|c|c|c|c|}
\hline \multirow[b]{2}{*}{ Age of minor child } & \multicolumn{3}{|c|}{$\begin{array}{l}\text { Percent of minor children } \\
\text { among parents in state } \\
\text { prison }\end{array}$} & \multicolumn{3}{|c|}{$\begin{array}{l}\text { Percent of minor children } \\
\text { among parents in federal } \\
\text { prison }\end{array}$} \\
\hline & Total & Male & Female & Total & Male & Female \\
\hline Total & $100.0 \% 1$ & $100.0 \%$ & $100.0 \%$ & $100.0 \%$ & $100.0 \%$ & $100.0 \%$ \\
\hline Less than 1 year & $2.4 \%$ & $2.5 \%$ & $1.6 \%$ & $0.7 \%$ & $0.7 \%$ & $1.1 \%$ \\
\hline 1-4 years & 20.0 & 20.3 & 16.7 & 15.1 & 15.3 & 12.6 \\
\hline 5-9 years & 30.2 & 30.3 & 29.1 & 33.8 & 34.0 & 30.1 \\
\hline 10-14 years & 31.6 & 31.4 & 33.8 & 35.1 & 35.0 & 35.8 \\
\hline 15-17 years & 15.8 & 15.5 & 18.8 & 15.3 & 15.0 & 20.4 \\
\hline
\end{tabular}

Table 4. Estimated number of minor children of state and federal inmates at time of admission, at interview, and at expected release, by gender, 2004

Estimated number of minor children of parents in state prison

Estimated number of minor children of parents in federal prison

Total Male Female Total Male Female

At admission* 1,596,100 1,463,400 $132,700 \quad 282,600 \quad 265,900 \quad 16,700$

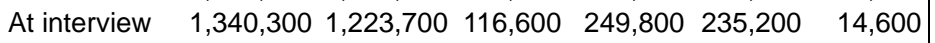

At expected

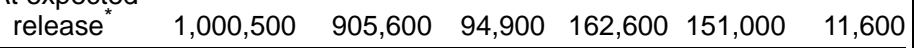

*Does not include children of parents in prison who did not report time served or time expected to be served.
Table 5. Percent of state and federal inmates who were parents of minor children, by age and gender, 2004

\begin{tabular}{|c|c|c|c|c|c|c|}
\hline \multirow{2}{*}{$\begin{array}{l}\text { Age of inmates } \\
\text { who were parents } \\
\text { of minor children }\end{array}$} & \multicolumn{3}{|c|}{$\begin{array}{l}\text { Percent of parents in } \\
\text { state prison }\end{array}$} & \multicolumn{3}{|c|}{$\begin{array}{l}\text { Percent of parents in } \\
\text { federal prison }\end{array}$} \\
\hline & Total & Male & Female & Total & Male & Female \\
\hline All inmates & $51.9 \%$ & $51.2 \%$ & $61.7 \%$ & $62.9 \%$ & $63.4 \%$ & $55.9 \%$ \\
\hline 24 or younger & $44.1 \%$ & $43.5 \%$ & $55.4 \%$ & $45.8 \%$ & $45.7 \%$ & $47.5 \%$ \\
\hline $25-34$ & 64.4 & 63.3 & 80.7 & 74.1 & 74.1 & 74.5 \\
\hline $35-44$ & 58.9 & 58.3 & 65.7 & 71.9 & 72.1 & 68.2 \\
\hline $45-54$ & 31.0 & 31.4 & 25.8 & 47.0 & 48.3 & 31.2 \\
\hline 55 or older & 12.6 & 12.9 & $\wedge$ & 23.8 & 25.3 & $\wedge$ \\
\hline
\end{tabular}

Note: See appendix table 16 for estimated total counts.

$\wedge$ Estimate not reported. Sample size too small (10 or fewer) to provide reliable data.

to 54 reported being a parent. The likelihood of being a parent in state prison was lowest among inmates age 55 or older (13\%). Among state prisoners in all age categories except age 45 to 54 , women were more likely than men to report being a parent. There was no difference in the prevalence of being a parent between men and women age 45 to 54.

Federal inmates age 25 to 34 (74\%) and age 35 to 44 (72\%) were more likely to report being a parent, compared to inmates in all other age categories. Forty-seven percent of inmates age 45 to 54 and $46 \%$ of inmates age 24 or younger reported being a parent. Federal inmates age 55 or older were least likely to report that they had minor children.

For men held in state prison, the likelihood of being a parent varied across racial categories (appendix table 4). Hispanic (57\%) and black (54\%) men were more likely than white $(45 \%)$ men to report being a parent. Findings were similar for men held in federal prison. White men (48\%) in federal prison were the least likely of all male inmates to report having children. Black (70\%) and Hispanic (69\%) men were equally likely to be parents. The likelihood of being a parent for white, black, and Hispanic women held in state prison did not vary by race. In federal prison, Hispanic women (63\%) were more likely than white women (47\%) to report being a parent.

In state prison, the likelihood of being a parent was most common among married inmates (71\%), compared to inmates who were separated (64\%), divorced (55\%), never married (45\%), or widowed (36\%). Among federal inmates, married inmates were more likely to report being a parent than inmates in all marital statuses except those inmates who were separated from their spouse. There was no difference in the prevalence of being a parent between married federal inmates and separated federal inmates. The likelihood of being a parent varied little by education for both state and federal inmates. 
Drug and public-order offenders in state and federal prisons were more likely than violent offenders to have children

Among male state prisoners, violent (47\%) and property $(48 \%)$ offenders were less likely to report having children than public-order (60\%) and drug (59\%) offenders (table 6). For women held in state prison, violent (57\%) offenders were less likely than drug (63\%), property (65\%), and public-order $(65 \%)$ offenders to be a mother.

The prevalence of being a parent differed by gender and offense for inmates held in state and federal prisons. For state inmates, female $(65 \%)$ property offenders were more likely to be a parent than male $(48 \%)$ property offenders. In federal prison, male (69\%) drug offenders were more likely than female (55\%) drug offenders to report having children.

Among men held in federal prison, drug offenders (69\%) were more likely than property (54\%) and violent (50\%) offenders to report having children (appendix table 5). Public-order offenders (62\%) were also more likely than violent offenders to report having children. For women in federal prison, the likelihood of being a mother did not differ by offense.

Inmates in state and federal prisons with a criminal history were more likely to be parents of minor children than those with no criminal history

The likelihood of being a parent in prison varied slightly based on criminal history, including prior probation, parole, and incarceration sentences. Prisoners with a criminal history were more likely to report being a parent than prisoners with no criminal history. In state prison, $53 \%$ of inmates with a criminal history reported having children, compared to $48 \%$ with no criminal history. Sixty-six percent of parents held in federal prison reported having a criminal history, compared to $57 \%$ of parents with no criminal history.

In state prison, drug recidivists (62\%)-offenders with a prior drug offense-had a higher likelihood of being a parent than violent (52\%) and other (54\%) recidivists. For women in state prison, and both men and women in federal prison, the likelihood of being a parent did not vary by type of recidivist (appendix table 6).

Male (50\%) and female (61\%) inmates in state prison who reported no prior incarceration sentences were equally likely to be a parent as male (53\%) and female (65\%) inmates with 10 or more prior incarcerations. In federal prison, findings were similar for men while women with no prior incarceration sentences (54\%) were less likely to be a mother than women who reported they had 10 or more prior incarcerations (81\%).
Fewer than half of parents in state prison lived with their minor children either in the month before arrest or just prior to incarceration

Thirty-seven percent of parents held in state prison reported living with at least one of their children in the month before arrest, $44 \%$ reported just prior to incarceration, and $48 \%$ reported at either time (table 7 ). Mothers were more likely than fathers to report living with at least one child. More than half of mothers held in state prison reported living with at least one of their children in the month before arrest, compared to $36 \%$ of fathers. More than 6 in 10 mothers reported living with their children just prior to incarceration or at either time, compared to less than half of fathers.

Parents held in federal prison were more likely than those held in state prison to report living with a child in the month before arrest, just prior to incarceration, or at either time (appendix table 7). Mothers in federal prison were more likely than fathers to report living with a child.

\begin{tabular}{|c|c|c|c|}
\hline Offense & Total & Male & Female \\
\hline All inmates & $51.9 \%$ & $51.2 \%$ & $61.7 \%$ \\
\hline Violent & $47.5 \%$ & $47.1 \%$ & $57.3 \%$ \\
\hline Property & 49.9 & 48.2 & 64.7 \\
\hline Drug & 59.6 & 59.3 & 62.5 \\
\hline Public-order & 59.9 & 59.6 & 65.0 \\
\hline
\end{tabular}

Note: See appendix table 17 for estimated total counts.

Table 7. Parents in state prison who reported living with their minor children in the month before arrest or just prior to incarceration, by gender, 2004

\begin{tabular}{llll} 
Lived with their minor children & Total & Male & Female \\
\hline In month before arrest & $37.1 \%$ & $35.5 \%$ & $55.3 \%$ \\
$\quad$ In two-parent household & 17.9 & 18.3 & 13.6 \\
$\quad$ In single-parent household & 19.2 & 17.2 & 41.7 \\
$\begin{array}{l}\text { Prior to incarceration } \\
\begin{array}{l}\text { Either in the month before arrest } \\
\text { or just prior to incarceration }\end{array}\end{array}$ & $43.8 \%$ & $42.4 \%$ & $60.6 \%$ \\
$\quad \begin{array}{lll}\text { Estimated number of parents } \\
\text { in state prison }\end{array}$ & $47.9 \%$ & $46.5 \%$ & $64.2 \%$ \\
& 636,300 & 585,200 & 51,100 \\
& & & \\
\end{tabular}


More than 4 in 10 mothers in state prison who had minor children were living in single-parent households in the month before arrest

Parents held in state prison were equally likely to report living with their children in a single-parent household (19\%) as they were to report living with their children in a twoparent household (18\%) in the month before arrest. Mothers were three times more likely to report living in a singleparent household (42\%) than in a two-parent household (14\%). Fathers reported similar percentages of living in single or two-parent households in the month before their arrest.

Parents held in federal prison were more likely overall to report having lived in two-parent versus single-parent households in the month before arrest. Mothers (52\%) were more than two and a half times more likely than fathers $(19 \%)$ to have lived in single-parent households.

\section{Fathers living with their minor child relied heavily on someone to provide daily care}

Mothers and fathers in state prison responded differently when asked who provided most of the daily care for their minor children. Among parents in state prison who had lived with their minor children just prior to incarceration, mothers $(77 \%)$ were almost three times more likely than fathers (26\%) to report that they had provided most of the daily care for their children (appendix table 8). Sixty-three percent of fathers reported sharing the daily care, compared to $18 \%$ of mothers. About 1 in 10 fathers relied on someone to provide daily care for their children, compared to 1 in 20 mothers. Similar results were found for mothers and fathers in federal prison.

Fathers most commonly reported the child's mother as current caregiver of their children, while mothers most commonly reported the child's grandparents

The other parent (84\%) was the most commonly reported caregiver for children of parents in state prison, followed by grandparents (15\%), and other relatives (6\%) (table 8 ). Three percent reported that their children were in the care of a foster home, agency, or institution.

Mothers and fathers in state prison provided different responses about their children's current caregivers. Eightyeight percent of fathers reported that at least one of their children was in the care of the child's mother, compared to $37 \%$ of mothers who reported the father as the child's current caregiver.
Mothers in state prison most commonly identified the child's grandmother (42\%) as the current caregiver. Nearly a quarter (23\%) identified other relatives as the current caregivers of their children. The percentage of fathers in prison who reported that their children were in the care of a grandmother (12\%) or other relative (5\%) was much smaller. Mothers (11\%) were 5 times more likely than fathers $(2 \%)$ to report that their children were in the care of a foster home, agency, or institution.

\section{About half of parents in state prison provided the primary financial support for their minor children}

Mothers (52\%) and fathers (54\%) in state prison were equally likely to report that they provided primary financial support for their minor children prior to their incarceration (appendix table 9). Three-quarters (75\%) reported employment in the month prior to their arrest. Parents who supported their children financially were more likely to have been employed (80\%) in the month prior to arrest and to report wages or salary (76\%) as income.

Of parents with minor children who did not provide primary financial support, $68 \%$ reported employment in the month before their arrest and $64 \%$ reported wages or salary as income. More than a third (36\%) of mothers in state prison reported government transfers such as welfare, Social Security, or compensation payment as income. Mothers were more likely than fathers to report receiving government transfers regardless of who provided the primary financial support for their children. The findings were similar for parents held in federal prison.

\begin{tabular}{|c|c|c|c|}
\hline Children's current caregiver ${ }^{\mathrm{a}}$ & Total & Male & Female \\
\hline Other parent & $84.2 \%$ & $88.4 \%$ & $37.0 \%$ \\
\hline Grandparent & $15.1 \%$ & $12.5 \%$ & $44.9 \%$ \\
\hline Grandmother & 14.0 & 11.6 & 42.1 \\
\hline Grandfather & 4.3 & 3.6 & 12.0 \\
\hline Other relatives & $6.2 \%$ & $4.7 \%$ & $22.8 \%$ \\
\hline Foster home or agency & $2.9 \%$ & $2.2 \%$ & $10.9 \%$ \\
\hline Friends, others ${ }^{b}$ & $2.9 \%$ & $2.4 \%$ & $7.8 \%$ \\
\hline $\begin{array}{l}\text { Estimated number of } \\
\text { parents in state prison }\end{array}$ & 636,300 & 585,200 & 51,100 \\
\hline
\end{tabular}

aIncludes all parents with minor children. Detail may sum to more than $100 \%$ because some prisoners had multiple minor children living with multiple caregivers.

bIncludes inmate's friends, friends of the inmate's children, cases where the parent reported that the child now lived alone, and others. 
Parents in state prison who provided primary financial support were more likely to report that they lived with their children in the month before arrest or just prior to incarceration (table 9). Among parents in state prison who provided the primary financial support to their children, mothers (89\%) were more likely than fathers (67\%) to report that they had lived with their children.

\section{More than three-quarters of state prison inmates who were parents of minor children reported that they had some contact with their children since admission}

Seventy percent of parents in state prison reported exchanging letters with their children, $53 \%$ had spoken with their children over the telephone, and $42 \%$ had a personal visit since admission (appendix table 10). ${ }^{1}$ Mothers were more likely than fathers to report having had any contact with their children. Mothers and fathers were equally likely

\footnotetext{
${ }^{1}$ Question was asked about contact with any child, which could include children 18 years of age or older.
}

\begin{tabular}{|c|c|c|c|}
\hline & Total & Male & Female \\
\hline $\begin{array}{l}\text { Provided primary financial support } \\
\text { Lived with minor child in the } \\
\text { month before arrest or prior } \\
\text { to incarceration }\end{array}$ & $54.0 \%$ & $54.1 \%$ & $51.9 \%$ \\
\hline $\begin{array}{l}\text { Did not provide primary financial } \\
\text { support } \\
\text { Lived with minor child in the } \\
\text { month before arrest or prior } \\
\text { to incarceration }\end{array}$ & $46.0 \%$ & $45.9 \%$ & $48.1 \%$ \\
\hline $\begin{array}{l}\text { Estimated number of parents } \\
\text { in state prison }\end{array}$ & 636,300 & 585,200 & 51,100 \\
\hline
\end{tabular}

to report having had personal visits with their children. A higher percentage of parents in federal prison reported contact with their children. In federal prison, $85 \%$ reported telephone contact, $84 \%$ had exchanged letters, and $55 \%$ reported having had personal visits.

More than three-quarters of state prison inmates who were parents of minor children reported that they had some contact with their children since admission (table 10). Thirtynine percent of fathers and $56 \%$ of mothers in state prison had at least weekly contact with their children since admission. Parents (86\%) in state prison who reported living with their minor children in the month before arrest or just before incarceration were more likely to report having contact with their children than parents (72\%) who had not lived with their children. Mothers (62\%) and fathers (49\%) who had lived with their children were more likely to report they had at least weekly contact with their children than mothers (44\%) and fathers (30\%) who had not lived with their children.

While the percent of parents in state prison who reported contact with their children varied little by expected release date, those having less time to serve reported more frequent contact with their children. About half $(47 \%)$ of parents who expected to be released within six months reported at least weekly contact with their children, compared to $39 \%$ who expected to be released in 12 to 59 months, and $32 \%$ in 60 or more months. Among parents who did not expect to be released, $22 \%$ reported at least weekly contact with their children.

Table 10. Frequency of contact with adult or minor children among state inmates who were parents of minor children, by gender, 2004

\begin{tabular}{|c|c|c|c|c|c|c|c|c|c|}
\hline & \multicolumn{3}{|c|}{ Any contact } & \multicolumn{3}{|c|}{ Weekly or more } & \multicolumn{3}{|c|}{ Monthly or less } \\
\hline & Total & Male & Female & Total & Male & Female & Total & Male & Female \\
\hline All parents in state prison & $78.6 \%$ & $78.1 \%$ & $85.0 \%$ & $39.9 \%$ & $38.5 \%$ & $55.7 \%$ & $38.8 \%$ & $39.6 \%$ & $29.3 \%$ \\
\hline \multicolumn{10}{|l|}{ Lived with minor children* } \\
\hline Yes & $86.0 \%$ & $85.5 \%$ & $89.7 \%$ & $50.1 \%$ & $48.6 \%$ & $62.3 \%$ & $35.9 \%$ & $36.9 \%$ & $27.4 \%$ \\
\hline No & 72.1 & 71.9 & 76.5 & 30.9 & 30.2 & 44.2 & 41.2 & 41.7 & 32.3 \\
\hline \multicolumn{10}{|c|}{ Time expected to serve until release } \\
\hline Less than 6 months & $78.5 \%$ & $77.7 \%$ & $84.8 \%$ & $47.3 \%$ & $45.9 \%$ & $56.9 \%$ & $31.2 \%$ & $31.7 \%$ & $27.9 \%$ \\
\hline $6-11$ months & 79.1 & 78.4 & 84.8 & 42.8 & 41.3 & 55.9 & 36.2 & 37.1 & 28.9 \\
\hline $12-59$ months & 79.0 & 78.5 & 86.7 & 39.4 & 38.4 & 54.9 & 39.6 & 40.1 & 31.8 \\
\hline 60 or more months & 78.6 & 78.5 & 80.6 & 32.3 & 31.7 & 47.9 & 46.3 & 46.8 & 32.8 \\
\hline No release expected & 74.0 & 74.0 & 74.8 & 22.4 & 21.3 & $\wedge$ & 51.6 & 52.7 & $\wedge$ \\
\hline
\end{tabular}

Note: See appendix table 18 for estimated total counts. The contact question included in the 2004 SISFCF asked about contact with any child, which could include children age 18 or older.

*Inmate lived with minor children in the month before arrest or just prior to incarceration.

${ }^{\wedge}$ Estimate not reported. Sample size too small (10 or fewer) to provide reliable data. 
Half of parents in state prison reported that they had a family member who had been incarcerated

Mothers in state prison (58\%) were more likely than fathers (49\%) to report having a family member who had also been incarcerated (table 11). Parents in state prison most commonly reported a brother (34\%), followed by a father (19\%). Among mothers in state prison, 13\% reported a sister and $8 \%$ reported a spouse. Six percent of fathers reported having a sister who had also been incarcerated; $2 \%$, a spouse.

While growing up, $40 \%$ of parents in state prison reported living in a household that received public assistance, 14\% reported living in a foster home, agency, or institution at some time during their youth, and $43 \%$ reported living with both parents most of the time (appendix table 11). Mothers $(17 \%)$ held in state prison were more likely than fathers (14\%) to report living in a foster home, agency, or institution at some time during their youth. Parents in federal prison reported lower percentages of growing up in a household that received public assistance (31\%) or living in a foster home, agency, or institution (7\%). These characteristics varied little by gender for parents held in federal prison.

More than a third (34\%) of parents in state prison reported that during their youth, their parents or guardians had abused alcohol or drugs. Mothers in state prison (43\%) were more likely than fathers $(33 \%)$ to have had this experience. Fewer parents (27\%) in federal prison reported having a parent or a guardian who had abused alcohol or drugs.

\begin{tabular}{|c|c|c|c|}
\hline \multicolumn{4}{|c|}{$\begin{array}{l}\text { Table 11. Family incarceration of state inmates who were } \\
\text { parents of minor children, by gender, } 2004\end{array}$} \\
\hline & Total & Male & Female \\
\hline Family member ever incarcerated & $49.6 \%$ & $48.9 \%$ & $58.4 \%$ \\
\hline Mother & 6.4 & 6.1 & 10.4 \\
\hline Father & 18.8 & 18.6 & 20.7 \\
\hline Brother & 34.4 & 34.2 & 36.8 \\
\hline Sister & 6.5 & 6.0 & 13.0 \\
\hline Child & 2.0 & 1.7 & 5.2 \\
\hline Spouse & 1.9 & 1.5 & 7.5 \\
\hline \multicolumn{4}{|c|}{ Estimated number of parents } \\
\hline
\end{tabular}

Mothers in state prison more likely than fathers to report homelessness, past physical or sexual abuse, and medical and mental health problems

Among parents in state prison, 9\% reported homelessness in the year before arrest, $20 \%$ had a history of physical or sexual abuse, and $41 \%$ reported a current medical problem. Fifty-seven percent of parents in state prison met the criteria for a mental health problem and $67 \%$ met the criteria for substance dependence or abuse (appendix table 12). ${ }^{2}$ In comparison, parents in federal prison reported lower percentages of homelessness (4\%) in the year before arrest, past physical or sexual abuse (11\%), current medical problems (36\%), mental health problems (43\%), and substance dependence or abuse (56\%).

Mothers in state prison were two times more likely than fathers to report homelessness in the year before arrest, four times more likely to report past physical or sexual abuse, and almost one and half times more likely to have either a current medical or mental health problem. The comparison by gender among parents held in federal prison was similar to those held in state prison, with the exception of homelessness in the year before arrest. Both male and female parents held in federal prison had similar rates $(4.0 \%)$ of homelessness in the year before arrest.

Reports from fathers in state prison that showed past physical or sexual abuse, current medical problems, mental health problems, and substance dependence or abuse didnot vary overall by living arrangement (table 12). However, fathers who had not lived with their children were three times more likely than those who had lived with their children to report homelessness in the year prior to arrest.

\footnotetext{
${ }^{2}$ Inmates met the criteria for a mental health problem if they had a recent history of a mental health problem in the year before arrest or since admission, or if they experienced, in the 12 months prior to the interview, symptoms of mental health disorders. See Mental Health Problems of Prison and Jail Inmates, <http://www.ojp.usdoj.gov/bjs/abstract/mhppji.htm>.
}

Table 12. Homelessness, physical/sexual abuse, medical/mental health problems, or substance dependence/abuse problems among state inmates who were parents of minor children, by living arrangement and gender, 2004

\begin{tabular}{|c|c|c|c|c|c|}
\hline & All parents in & Lived with $n$ & or children* & Did not live $n$ & nor children* \\
\hline & state prison & Male & Female & Male & Female \\
\hline Homelessness in year before arrest & $8.9 \%$ & $4.0 \%$ & $8.5 \%$ & $12.0 \%$ & $28.7 \%$ \\
\hline Ever physical/sexual abuse & 19.9 & 16.1 & 59.7 & 15.7 & 72.4 \\
\hline Current medical problem & 40.6 & 39.7 & 50.0 & 39.6 & 57.6 \\
\hline Any mental health problem & 56.5 & 54.5 & 72.8 & 55.2 & 75.3 \\
\hline Any substance dependence/abuse & 67.4 & 65.0 & 63.6 & 68.8 & 81.5 \\
\hline Estimated number of parents in state prison & 636,300 & 272,200 & 32,800 & 313,000 & 18,300 \\
\hline $\begin{array}{l}\text { Note: Measures of substance dependence or abuse } \\
\text { Manual of Mental Disorders," fourth edition (DSM-IV } \\
\text { www.ojp.usdoj.gov/bjs/abstract/dudsfp04.htm }>\text { and } \\
\text { pji.htm>. } \\
\text { *Inmate lived with minor children in the month befor }\end{array}$ & $\begin{array}{l}\text { mental health } \\
\text { r details, see } \square \\
\text { al Health Prob } \\
\text { est or just prior }\end{array}$ & $\begin{array}{l}\text { ms were bas } \\
\text { se and Depe } \\
\text { f Prison and } \\
\text { arceration. }\end{array}$ & $\begin{array}{l}\text { on criteria } \\
\text { nce, State } \\
\text { I Inmates, }\end{array}$ & $\begin{array}{l}\text { fied in the "Dic } \\
\text { Federal Prisor } \\
\text { //www.ojp.usd }\end{array}$ & $\begin{array}{l}\text { ic and Statistic } \\
\text { 004, <http:// } \\
\text { /bjs/abstract/n }\end{array}$ \\
\hline
\end{tabular}


Mothers held in state prison who had not lived with their children were three times more likely to report homelessness $(29 \%)$ than those who had lived with their children (9\%). Mothers who had not lived with their children were also more likely to report past physical and sexual abuse, current medical problems, and substance dependence or abuse than those who had lived with their children.

\section{More than 4 in 10 parents in the nation's prisons who met the criteria for substance dependence or abuse had received treatment since admission}

About 4 in 10 parents in state prison who met the criteria for substance dependence or abuse reported ever receiving treatment for drug or alcohol abuse; 56\% reported participating in other drug or alcohol abuse programs (appendix table 13). Forty-three percent of parents who met the criteria reported treatment since admission. For fathers (10\%) and mothers (14\%), placement in a residential facility or unit for drug or alcohol abuse was the most common treatment since admission. Parents held in federal prison who met the criteria for substance dependence or abuse reported similar percentages of alcohol or drug treatment and program participation.
Of parents in state prison who had a mental health problem, 46\% reported ever receiving treatment. About a third (31\%) had been treated since admission. Prescription medication was the most common treatment for both those who had reported ever having treatment (38\%) and for those who had received treatment since admission (25\%).

About a third (33\%) of parents in state prison with a mental health problem reported that they had ever received therapy and $18 \%$ reported they had ever had an overnight hospital stay. A fifth (21\%) of parents with a mental health problem reported that they had received therapy since admission; $5 \%$ had an overnight hospital stay.

Mothers were more likely than fathers to report treatment for mental health problems either before or after admission to a state prison. In state prison, prescribed medication was the most common treatment for parents with a mental health problem.

While parents in federal prison were less likely than those in state prison to report mental health treatment, the patterns by gender were similar for both. Participation in alcohol, drug, or mental health treatment did not vary by whether parents had lived with their children in the month before arrest or just prior to incarceration (table 13).

Table 13. Alcohol or drug and mental health treatment history of inmates in state prison who were parents of minor children and who had an alcohol or drug or mental health problem, by living arrangement and gender, 2004

\begin{tabular}{|c|c|c|c|c|c|}
\hline & \multirow{2}{*}{$\begin{array}{l}\text { All parents in } \\
\text { state prison }\end{array}$} & \multicolumn{2}{|c|}{ Lived with minor children $^{\mathrm{a}}$} & \multicolumn{2}{|c|}{ Did not live with minor children } \\
\hline & & Male & Female & Male & Female \\
\hline \multicolumn{6}{|l|}{ Alcohol or drug treatment ${ }^{b}$} \\
\hline Ever any treatment or programs & $69.8 \%$ & $68.9 \%$ & $74.3 \%$ & $69.6 \%$ & $77.2 \%$ \\
\hline Received treatment since admission & 42.9 & 41.7 & 46.4 & 43.0 & 49.8 \\
\hline $\begin{array}{l}\text { Estimated number of parents who had an alcohol or drug } \\
\text { problem }\end{array}$ & 428,600 & 177,900 & 20,900 & 215,000 & 14,800 \\
\hline \multicolumn{6}{|l|}{ Mental health treatment ${ }^{c}$} \\
\hline Ever any treatment & $46.4 \%$ & $42.2 \%$ & $70.4 \%$ & $44.1 \%$ & $77.3 \%$ \\
\hline Received treatment since admission & 30.9 & 25.6 & 52.4 & 29.7 & 57.8 \\
\hline $\begin{array}{l}\text { Estimated number of parents who had a mental health } \\
\text { problem }\end{array}$ & 359,200 & 148,700 & 23,900 & 172,900 & 13,700 \\
\hline
\end{tabular}

anmate lived with minor children in the month before arrest or just prior to incarceration.

${ }^{b}$ Based on parents in state prison who had an alcohol or drug problem.

${ }^{\mathrm{C}}$ Based on parents in state prison who had a mental health problem. 
Among parents in state prison, two-thirds reported they had a work assignment; over half had attended self-help or improvement classes since admissions

In state prison, about 7 in 10 mothers (70\%) and fathers $(67 \%)$ reported participating in work assignments since admission (appendix table 14). About two-thirds (65\%) of mothers and more than half (57\%) of fathers had attended self-help or improvement classes. While mothers and fathers were equally likely to report participating in employment and educational programming, mothers $(27 \%)$ were about two and a half times more likely than fathers (11\%) to attend parenting or childrearing classes. Mothers and fathers (both 62\%) were equally likely to report having a high school diploma or GED at admission.
Parents held in federal prison reported participating in work assignments and self-help programs and having a high school diploma or GED more frequently than parents in state prison. More than 9 in 10 parents in federal prison reported participating in a work assignment. Since admission, more than 7 in 10 had attended self-help or improvement classes. About 7 in 10 reported having a high school diploma or GED upon admission.

Similar percentages of participation in self-help or improvement classes were found between mothers and fathers in state prison who had lived with their children and those who had not lived with their children prior to arrest or incarceration (table 14). Mothers who had lived with their children prior to arrest or incarceration (72\%) were more likely than mothers who had not lived with their children (67\%) to participate in work assignments.

\begin{tabular}{|c|c|c|c|c|c|}
\hline & \multirow{2}{*}{$\begin{array}{l}\text { All parents in } \\
\text { state prison }\end{array}$} & \multicolumn{2}{|c|}{ Lived with minor children $^{a}$} & \multicolumn{2}{|c|}{ Did not live with minor children ${ }^{a}$} \\
\hline & & Male & Female & Male & Female \\
\hline Work assignments $^{b}$ & $66.8 \%$ & $67.9 \%$ & $72.2 \%$ & $65.7 \%$ & $66.6 \%$ \\
\hline Self-help or improvement classes since admission & $57.2 \%$ & $57.4 \%$ & $65.4 \%$ & $55.8 \%$ & $63.4 \%$ \\
\hline Parenting or childrearing classes & 11.9 & 12.1 & 29.7 & 9.3 & 22.5 \\
\hline Employment programs & 30.4 & 30.6 & 33.2 & 30.1 & 26.9 \\
\hline Vocational or job-training program & 26.5 & 26.2 & 27.0 & 26.8 & 22.2 \\
\hline Employment counseling & 9.4 & 9.6 & 12.4 & 8.8 & 11.3 \\
\hline Education programs ${ }^{\mathrm{C}}$ & 30.3 & 29.4 & 33.2 & 30.8 & 31.5 \\
\hline Other pre-release programs ${ }^{d}$ & 31.2 & 32.0 & 39.3 & 29.3 & 39.4 \\
\hline Had GED or high school diploma upon admission & $62.4 \%$ & $63.0 \%$ & $65.5 \%$ & $62.2 \%$ & $56.4 \%$ \\
\hline Estimated number of parents in state prison & 636,300 & 272,200 & 32,800 & 313,000 & 18,300 \\
\hline \multicolumn{6}{|c|}{ aInmate lived with their minor children in the month before arrest or just prior to incarceration. } \\
\hline \multicolumn{6}{|c|}{${ }^{\mathrm{b}}$ Includes work assignments both inside and outside the prison. } \\
\hline \multicolumn{6}{|c|}{ 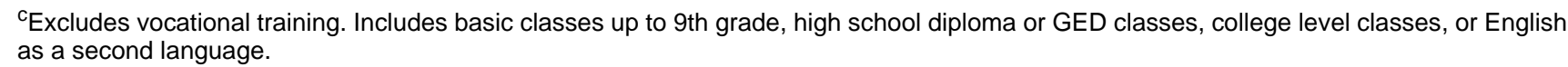 } \\
\hline \multicolumn{6}{|c|}{$\begin{array}{l}\text { dIncludes inmate assistance/counseling groups, inmate self-help/personal improvement groups, including parent awareness groups, life } \\
\text { skills/community adjustment classes, and other pre-release programs. }\end{array}$} \\
\hline
\end{tabular}


Mothers in prison had served less time at time of interview and expected to be released in a shorter amount of time than fathers

Over half $(52 \%)$ of parents in state prison had served between 12 and 59 months at the time of their interview (appendix table 15). A quarter (26\%) had been in prison 60 months or more. Mothers and fathers were equally likely to have been in prison for 12 to 59 months. For longer lengths of stay, mothers $(13 \%)$ were less likely than fathers $(27 \%)$ to have been in prison for 60 or more months.

About 4 in 10 mothers in state prison expected to be released within 6 months. An additional 21\% expected to be released in 6 to 11 months. Among fathers in state prison, a quarter expected to be released in less than 6 months and $15 \%$ percent expected to be released in 6 to 11 months. Compared to mothers in federal prison, fathers had served more of their sentence at the time of their interviews and expected to have a longer time remaining until their release.

Time served and time expected until release varied little for fathers by whether they had lived with their children in the month before arrest or just prior to incarceration while differences were found among women (table 15). Compared to mothers who had not lived with their children in the month before arrest or just prior incarceration (46\%), mothers who had lived with their children (39\%) were less likely to expect to be released in less than 6 months.

Table 15. Time served since admission and time to be served until expected release among state inmates who were parents of minor children, by gender, 2004

\begin{tabular}{|c|c|c|c|c|c|}
\hline & \multirow[b]{2}{*}{ All parents in state prison } & \multicolumn{2}{|c|}{ Lived with minor children $^{\mathrm{a}}$} & \multicolumn{2}{|c|}{ Did not live with minor children ${ }^{\mathrm{a}}$} \\
\hline & & Male & Female & Male & Female \\
\hline \multicolumn{6}{|l|}{ Time served since admission ${ }^{b}$} \\
\hline $6-11$ months & 13.1 & 11.7 & 19.9 & 13.3 & 19.4 \\
\hline $12-59$ months & 51.9 & 52.5 & 47.8 & 51.8 & 53.8 \\
\hline $60+$ months & 25.5 & 27.4 & 14.5 & 26.1 & 9.0 \\
\hline $6-11$ months & 15.4 & 15.0 & 20.5 & 14.8 & 20.3 \\
\hline $12-59$ months & 37.9 & 37.6 & 30.2 & 39.8 & 26.4 \\
\hline $60+$ months & 17.8 & 19.6 & 9.1 & 17.7 & 6.4 \\
\hline No release expected & 2.3 & 2.4 & 1.2 & 2.3 & $\wedge$ \\
\hline Estimated number of parents in state prison & 636,300 & 272,200 & 32,800 & 313,000 & 18,300 \\
\hline
\end{tabular}

$\wedge^{\wedge}$ Estimate not reported. Sample size too small (10 or fewer) to provide reliable data.

Inmate lived with minor children in the month before arrest or just prior to incarceration.

${ }^{b}$ Based on time served from admission until time of interview.

${ }^{\mathrm{C}}$ Based on time from interview to expected date of release. 


\section{Methodology}

Survey of Inmates in State and Federal Correctional Facilities

The Survey of Inmates in State and Federal Correctional Facilities (SISFCF), 2004, is comprised of two separate surveys. One survey is conducted in state adult correctional facilities and the other is conducted in federal correctional facilities. The surveys provide nationally representative data on state prison inmates and sentenced federal inmates. Both surveys use the same questionnaire and a stratified two-stage sample design where facilities are selected in the first stage and inmates to be interviewed in the second stage.

The state prison sample was selected from a universe of 1,585 facilities that were either enumerated in the 2000 Census of State and Federal Correctional Facilities (CSFCF), or had opened between the completion of the Census and April 1, 2003. A total of 287 state prisons participated in the survey; 2 state prisons refused, 11 were closed or had no inmates to survey, and 1 was erroneously included in the universe.

The federal prison sample was selected from 148 prisons and satellite facilities holding inmates on January 4, 2003. Thirty-nine of the 40 federal prisons selected participated in the survey.

A total of 14,499 inmates in the state facilities were interviewed; 1,653 inmates refused to participate, resulting in a second-stage nonresponse rate of $10.2 \%$. A total of 3,686 inmates in federal facilities were interviewed and 567 refused to participate, for a second-stage nonresponse rate of $13.3 \%$. After the initial sample of inmates, a secondary sample of 1 in 3 drug offenders was selected for participation in the federal survey.

\section{Accuracy of the estimates}

The accuracy of the 2004 SISFCF depends on sampling and measurement errors. Sampling errors occur by chance because a sample rather than a complete enumeration of the population was conducted. Measurement error can be attributed to many sources, such as nonresponse, recall difficulties, differences in the interpretation of questions among inmates, and processing errors.

The sampling error, as measured by an estimated standard error, varies by the size of the estimate and the size of the base population. These standard errors may be used to construct confidence intervals around percentages. For example, the 95-percent confidence interval around the percentage of state inmates who reported being a parent is approximately $51.9 \%$ plus or minus 1.96 times $1.41 \%$ (or $49.1 \%$ to $54.7 \%$ ).
These standard errors may also be used to test the statistical significance of the difference between two sample statistics by pooling the standard errors of the two sample estimates. For example, the standard error of the difference between male and female state inmate parents who lived with their children in the month before arrest or just prior to incarceration would be $3.69 \%$ (or the square root of the sum of the squared standard errors for each group). The 95\% confidence interval around the difference would be $1.96 \%$ times $3.69 \%$ (or $7.23 \%$ ). Since the difference of $17.7 \%(64.2 \%$ minus $46.5 \%)$ is greater than $7.2 \%$, the difference would be considered statistically significant. Differences discussed in this report were significant at the $95 \%$ confidence level.

\section{Number of parents in prison who had minor children}

To estimate the number of parents by gender in the 1991, 1997, and 2004 SISFCF survey years, the distribution of parents from each of the survey years was applied to the prisoner custody population by gender for that specific year. In 1999 and 2007, the surveys were not conducted. To estimate the number of parents by gender in 1999, the distribution of parents from the 1997 SISFCF was applied to the prisoner custody population by gender in 1999. The distribution of parents by gender from the 2004 SISFCF was used to estimate the number of parents in prison at midyear 2007, by applying the distribution to the midyear 2007 prisoner custody population by gender.

In 2007, 2004, and 1999, the total federal custody population included inmates held in privately operated facilities and community corrections centers (30,379 in 2007; 24,768 in 2004 ; and 3,828 in privately operated facilities in 1999). In 1991 and 1997 the number of inmates in these facilities was not known.

The 2007 estimates of the number of parents by race and gender were calculated based on the 2004 SISFCF distribution of parents, which was then applied to the midyear 2007 custody population, by race and gender. The 2004 estimates of the number of parents in prison by race and gender were calculated using the same method except the 2004 SISFCF distribution was applied to the midyear 2004 custody population, by race and gender.

\section{Number of minor children of parents in prison}

For this report, published estimates for 1991, 1997, and 1999 were re-estimated to ensure comparability for the period covered. The 2004 SISFCF allowed prisoners to report a maximum of ten children. The 1997 SISFCF only allowed prisoners to report a maximum of six children and the 1991 SISFCF only allowed prisoners to report a maximum of five children. The 1997 distribution for six children was used to estimate the number of prisoners with six children in 1991. The 2004 distribution for seven through ten children was used to estimate the number of prisoners with seven through ten children in both 1991 and 1997. 
Washington, DC 20531

Official Business

Penalty for Private Use $\$ 300$

\section{Revised 1/8/09}

For each year, the estimated number of parents by gender was multiplied by the number of minor children reported by male and by female inmates. The estimates were then summed by gender for each year and reported as the totals. Because this estimation method was used, estimates presented in this report may not be comparable to previously published BJS reports. See Incarcerated Parents and Their Children at <http://www.ojp.usdoj.gov/bjs/ abstract/iptc.htm>.

The 2007 estimates by race and gender for the number of minor children of parents in prison were calculated based on the 2004 SISFCF distribution of parents and the number of minor children they reported. This distribution was then applied to the midyear 2007 custody population by race and gender. The estimated number of parents by race and gender was multiplied by the number of minor children they reported. The estimates were summed by race and gender for each year and reported as the totals. The 2004 race and gender estimates for the number of minor children of parents in prison were calculated using this same method except the 2004 SISFCF distribution was applied to the midyear 2004 custody population, by race and gender.
The Bureau of Justice Statistics is the statistical agency of the U.S. Department of Justice. Jeffrey L. Sedgwick is director.

This Special Report was written by Lauren E. Glaze and Laura M. Maruschak. William J. Sabol, Ph.D. and Christopher J. Mumola provided statistical review. Lara E. Allen and Margaret E. Noonan verified the report.

Georgette Walsh edited the report, Tina Dorsey produced the report, and Jayne Robinson prepared the report for final printing, under the supervision of Doris J. James.

August 2008, NCJ 222984

This report in portable document format and in ASCII and its related statistical data and tables (includes 20 appendix tables) are available at the BJS World Wide Web Internet site: <http:// www.ojp.usdoj.gov/bjs/abstract/pptmc.htm>.

\section{Office of Justice Programs}

Innovation • Partnerships • Safer Neighborhoods $<$ http://www.ojp.usdoj.gov>. 


\begin{tabular}{|c|c|c|c|c|c|c|c|}
\hline \multicolumn{8}{|c|}{$\begin{array}{l}\text { Appendix table 1. Estimated number of parents in state and federal prisons and their minor } \\
\text { children, by inmate's gender }\end{array}$} \\
\hline & \multirow[b]{2}{*}{ Total } & \multicolumn{3}{|c|}{ Parents in state prison } & \multicolumn{3}{|c|}{ Parents in federal prison ${ }^{\mathrm{a}}$} \\
\hline & & Total & Male & Female & Total & Male & Female \\
\hline \multicolumn{8}{|c|}{ Number of parents } \\
\hline 2007 & 809,800 & 686,000 & 627,800 & 58,200 & 123,800 & 116,400 & 7,400 \\
\hline $2004^{b}$ & 754,900 & 644,100 & 592,300 & 51,800 & 110,800 & 104,200 & 6,600 \\
\hline 1999 & 721,500 & 642,300 & 593,800 & 48,500 & 79,200 & 74,100 & 5,100 \\
\hline 1997 & 649,500 & 587,000 & 544,100 & 42,900 & 62,500 & 58,500 & 4,000 \\
\hline 1991 & 452,500 & 413,100 & 386,500 & 26,600 & 39,400 & 36,500 & 2,900 \\
\hline \multicolumn{8}{|c|}{ Number of minor children } \\
\hline 2007 & $1,706,600$ & $1,427,500$ & $1,296,500$ & 131,000 & 279,100 & 262,700 & 16,400 \\
\hline $2004^{b}$ & $1,590,100$ & $1,340,300$ & $1,223,700$ & 116,600 & 249,800 & 235,200 & 14,600 \\
\hline $1999^{c}$ & $1,515,200$ & $1,338,900$ & $1,223,400$ & 115,500 & 176,300 & 165,700 & 10,600 \\
\hline $1997^{\mathrm{C}}$ & $1,362,900$ & $1,223,800$ & $1,121,400$ & 102,400 & 139,100 & 130,800 & 8,300 \\
\hline $1991^{\mathrm{C}}$ & 945,600 & 860,300 & 802,300 & 58,000 & 85,100 & 79,200 & 5,900 \\
\hline \multicolumn{8}{|c|}{ Note: See Methodology for details about estimation methods. } \\
\hline \multicolumn{8}{|c|}{$\begin{array}{l}{ }^{a} \text { Estimates were based on the prisoner custody population in each year. The total custody population included } \\
\text { inmates held in privately operated facilities and community corrections centers ( } 30,379 \text { in } 2007 ; 24,768 \text { in } 2004 \text {; and } \\
3,828 \text { inmates in privately operated facilities in 1999). In } 1991 \text { and } 1997 \text {, the number of inmates in these facilities } \\
\text { was not known. }\end{array}$} \\
\hline \multicolumn{8}{|c|}{$\begin{array}{l}{ }^{\mathrm{b}} \text { Numbers were estimated based on the June } 30,2004, \text { custody population in state }(1,241,034) \text { and federal } \\
(176,156) \text { prisons. }\end{array}$} \\
\hline${ }^{\mathrm{c}}$ Estim & nparable to $\mathrm{p}$ & reviously publ & ished BJS re & orts. See $N$ & hodology fo & more deta & \\
\hline
\end{tabular}

\begin{tabular}{|c|c|c|c|c|c|c|c|c|}
\hline \multicolumn{9}{|c|}{$\begin{array}{l}\text { Appendix table 2. Estimated number of parents in state and federal prisons and their minor } \\
\text { children, by inmate's gender, race, and Hispanic origin, } 2004 \text { and } 2007\end{array}$} \\
\hline & \multicolumn{4}{|c|}{ Male } & \multicolumn{4}{|c|}{ Female } \\
\hline & Total $^{\mathrm{a}}$ & White $^{\mathrm{b}}$ & Black $^{b}$ & Hispanic & Total $^{\mathrm{a}}$ & White $^{b}$ & Black $^{b}$ & Hispanic \\
\hline \multicolumn{9}{|c|}{ State inmates } \\
\hline \multicolumn{9}{|c|}{ Number of parents } \\
\hline 2007 & 627,800 & 197,800 & 262,400 & 127,600 & 58,200 & 29,000 & 16,100 & 8,800 \\
\hline $2004^{c}$ & 592,300 & 189,800 & 279,500 & 113,100 & 51,800 & 23,300 & 19,000 & 8,200 \\
\hline \multicolumn{9}{|c|}{ Number of children } \\
\hline 2007 & $1,296,500$ & 373,400 & 577,900 & 263,500 & 131,000 & 60,000 & 39,600 & 22,900 \\
\hline $2004^{c}$ & $1,223,700$ & 358,000 & 611,600 & 233,000 & 116,600 & 47,900 & 45,700 & 21,000 \\
\hline \multicolumn{9}{|c|}{ Federal inmates } \\
\hline \multicolumn{9}{|c|}{ Number of parents } \\
\hline 2007 & 116,400 & 25,900 & 57,000 & 32,500 & 7,400 & 2,700 & 2,200 & 2,300 \\
\hline $2004^{\mathrm{c}}$ & 104,200 & 20,900 & 49,300 & 31,000 & 6,600 & 2,000 & 2,100 & 2,200 \\
\hline \multicolumn{9}{|c|}{ Number of children } \\
\hline 2007 & 262,700 & 45,100 & 144,800 & 71,200 & 16,400 & 5,600 & 5,100 & 5,200 \\
\hline $2004^{c}$ & 235,200 & 36,300 & 125,400 & 67,800 & 14,600 & 4,200 & 4,900 & 4,900 \\
\hline \multicolumn{9}{|c|}{ Note: See Methodology for estimation methods. } \\
\hline \multirow{2}{*}{\multicolumn{9}{|c|}{$\begin{array}{l}\text { alncludes other races. Other races include American Indians, Alaska Natives, Asians, Native Hawaiians, other Pacific } \\
\text { Islanders, and persons identifying two or more races. } \\
{ }^{b} \text { Excludes persons of Hispanic or Latino origin. }\end{array}$}} \\
\hline & & & & & & & & \\
\hline \multicolumn{9}{|c|}{$\begin{array}{l}\text { CNumbers were estimated based on the June } 30,2004 \text { custody population in state }(1,241,034) \text { and federal }(176,156) \\
\text { prisons. }\end{array}$} \\
\hline
\end{tabular}




\begin{tabular}{|c|c|c|c|c|c|}
\hline \multicolumn{6}{|c|}{$\begin{array}{l}\text { Appendix table } 3 \text {. State and federal inmates who reported having minor children } \\
\text { by gender, race, and Hispanic origin, } 2004\end{array}$} \\
\hline & \multirow[b]{2}{*}{$\begin{array}{l}\text { Percent of inmates } \\
\text { with minor children }\end{array}$} & \multicolumn{4}{|c|}{ Number of minor children } \\
\hline & & 1 & 2 & 3 & 4 or more \\
\hline State inmates & $51.9 \%$ & 22.5 & 14.8 & 8.1 & 6.5 \\
\hline Male* & $51.2 \%$ & 22.7 & 14.4 & 7.8 & 6.3 \\
\hline White, non-Hispanic & $44.8 \%$ & 21.6 & 12.9 & 6.5 & 3.8 \\
\hline Black, non-Hispanic & $54.0 \%$ & 23.3 & 14.4 & 7.9 & 8.4 \\
\hline Hispanic & $57.0 \%$ & 23.4 & 17.6 & 9.7 & 6.3 \\
\hline Female* $^{\star}$ & $61.7 \%$ & 20.7 & 19.3 & 12.4 & 9.3 \\
\hline White, non-Hispanic & $61.8 \%$ & 23.0 & 21.7 & 10.6 & 6.4 \\
\hline Black, non-Hispanic & $61.0 \%$ & 18.1 & 17.8 & 14.1 & 11.1 \\
\hline Hispanic & $64.1 \%$ & 18.3 & 15.9 & 14.1 & 15.8 \\
\hline Federal inmates & $62.9 \%$ & 24.4 & 17.8 & 10.9 & 9.8 \\
\hline Male* $^{*}$ & $63.4 \%$ & 24.8 & 17.9 & 10.9 & 9.9 \\
\hline White, non-Hispanic & $47.8 \%$ & 26.2 & 12.7 & 6.3 & 2.5 \\
\hline Black, non-Hispanic & $70.0 \%$ & 24.2 & 18.1 & 12.9 & 14.8 \\
\hline Hispanic & $68.5 \%$ & 23.4 & 23.7 & 12.5 & 8.9 \\
\hline Female $^{\star}$ & $55.9 \%$ & 19.5 & 17.0 & 10.7 & 8.7 \\
\hline White, non-Hispanic & $47.4 \%$ & 17.9 & 14.6 & 8.5 & 6.5 \\
\hline Black, non-Hispanic & $55.2 \%$ & 18.1 & 16.3 & 10.2 & 10.6 \\
\hline Hispanic & $63.4 \%$ & 21.6 & 18.2 & 13.9 & 9.6 \\
\hline \multicolumn{6}{|c|}{$\begin{array}{l}\text { Note: See appendix table } 16 \text { for estimated total counts. } \\
\text { *Includes inmates of other races. Other races include American Indians, Alaska Natives, } \\
\text { Asians, Native Hawaiians, other Pacific Islanders, and persons identifying two or more races. }\end{array}$} \\
\hline
\end{tabular}

\begin{tabular}{|c|c|c|c|c|c|c|}
\hline \multicolumn{7}{|c|}{$\begin{array}{l}\text { Appendix table } 4 \text {. Percent of state and federal in } \\
\text { of minor children, by selected characteristics an }\end{array}$} \\
\hline & \multicolumn{3}{|c|}{ Parents in state prison } & \multicolumn{3}{|c|}{ Parents in federal prison } \\
\hline & Total & Male & Female & Total & Male & Female \\
\hline All inmates & $51.9 \%$ & $51.2 \%$ & $61.7 \%$ & $62.9 \%$ & $63.4 \%$ & $55.9 \%$ \\
\hline \multicolumn{7}{|l|}{ Race } \\
\hline White, non-Hispanic & $46.3 \%$ & $44.8 \%$ & $61.8 \%$ & $47.8 \%$ & $47.8 \%$ & $47.4 \%$ \\
\hline Black, non-Hispanic & 54.4 & 54.0 & 61.0 & 69.2 & 70.0 & 55.2 \\
\hline Hispanic & 57.4 & 57.0 & 64.1 & 68.1 & 68.5 & 63.4 \\
\hline Other race* & 51.5 & 50.8 & 59.6 & 61.8 & 61.9 & 60.7 \\
\hline \multicolumn{7}{|l|}{ Marital status } \\
\hline Married & $71.3 \%$ & $71.3 \%$ & $71.0 \%$ & $75.7 \%$ & $76.9 \%$ & $60.2 \%$ \\
\hline Widowed & 36.2 & 35.3 & 40.9 & 36.9 & 38.2 & 33.2 \\
\hline Divorced & 55.0 & 54.7 & 59.0 & 58.8 & 59.0 & 56.1 \\
\hline Separated & 64.2 & 63.9 & 66.4 & 68.9 & 68.8 & 69.7 \\
\hline Never married & 44.6 & 43.7 & 60.6 & 57.7 & 58.1 & 52.4 \\
\hline \multicolumn{7}{|l|}{ Education completed } \\
\hline 8th grade or less & $49.5 \%$ & $48.6 \%$ & $61.8 \%$ & $65.6 \%$ & $66.2 \%$ & $57.6 \%$ \\
\hline Some high school & 55.2 & 54.6 & 63.8 & 70.5 & 71.0 & 64.3 \\
\hline GED & 51.3 & 50.6 & 64.1 & 62.4 & 62.8 & 56.6 \\
\hline High school graduate & 52.1 & 51.6 & 58.7 & 63.9 & 64.6 & 54.8 \\
\hline Some college or more & 48.5 & 47.3 & 59.2 & 54.6 & 55.1 & 49.8 \\
\hline \multicolumn{7}{|l|}{ U.S. citizenship } \\
\hline Citizen & $51.6 \%$ & $50.8 \%$ & $61.8 \%$ & $62.2 \%$ & $62.7 \%$ & $54.8 \%$ \\
\hline Non-citizen & 56.7 & 56.6 & 64.7 & 67.5 & 67.7 & 64.2 \\
\hline
\end{tabular}




\begin{tabular}{|c|c|c|c|c|c|c|}
\hline \multicolumn{7}{|c|}{$\begin{array}{l}\text { Appendix table } 5 \text {. Percent of state and federal i } \\
\text { minor children, by current offense and gender, }\end{array}$} \\
\hline \multirow{2}{*}{ Current offense } & \multicolumn{3}{|c|}{ Parents in state prison } & \multicolumn{3}{|c|}{ Parents in federal prison } \\
\hline & Total & Male & Female & Total & Male & Female \\
\hline All inmates & $51.9 \%$ & $51.2 \%$ & $61.7 \%$ & $62.9 \%$ & $63.4 \%$ & $55.9 \%$ \\
\hline Violent & $47.5 \%$ & $47.1 \%$ & $57.3 \%$ & $49.9 \%$ & $49.8 \%$ & $52.4 \%$ \\
\hline Homicide ${ }^{\mathrm{a}}$ & 40.3 & 39.9 & 46.6 & 51.6 & 51.7 & $\wedge$ \\
\hline Sexual assault ${ }^{b}$ & 45.4 & 45.3 & 61.9 & 30.7 & 30.1 & $\wedge$ \\
\hline Robbery & 47.0 & 46.5 & 59.6 & 49.5 & 49.5 & 49.2 \\
\hline Assault & 56.9 & 56.5 & 64.2 & 56.2 & 56.5 & $\wedge$ \\
\hline Property & $49.9 \%$ & $48.2 \%$ & $64.7 \%$ & $53.8 \%$ & $53.5 \%$ & $55.5 \%$ \\
\hline Burglary & 44.4 & 43.8 & 61.4 & 29.0 & $\wedge$ & $\wedge$ \\
\hline Larceny & 49.9 & 47.8 & 61.8 & 40.9 & $\wedge$ & $\wedge$ \\
\hline Motor vehicle theft & 52.0 & 51.2 & 67.6 & 43.8 & $\wedge$ & $\wedge$ \\
\hline Fraud & 60.2 & 56.8 & 68.1 & 58.7 & 59.2 & 56.5 \\
\hline Drug & $59.6 \%$ & $59.3 \%$ & $62.5 \%$ & $67.6 \%$ & $68.7 \%$ & $54.5 \%$ \\
\hline Possession & 56.9 & 55.9 & 64.3 & 63.0 & 64.5 & $\wedge$ \\
\hline Trafficking & 61.3 & 61.3 & 61.7 & 67.9 & 68.9 & 55.9 \\
\hline Public-order & $59.9 \%$ & $59.6 \%$ & $65.0 \%$ & $62.4 \%$ & $62.3 \%$ & $64.7 \%$ \\
\hline Weapons & 64.9 & 64.9 & 66.4 & 63.8 & 63.8 & 65.6 \\
\hline DWI & 52.9 & 52.6 & 59.3 & 38.7 & $\wedge$ & $\wedge$ \\
\hline \multicolumn{7}{|c|}{$\begin{array}{l}\text { Note: See appendix table } 17 \text { for estimated total counts. } \\
{ }^{\wedge} \text { Estimate not reported. Sample size too small (10 or fewer) to provide reliable data. } \\
\text { a Includes murder and manslaughter. } \\
{ }^{b} \text { Includes rape and other sexual assault. }\end{array}$} \\
\hline
\end{tabular}

\begin{tabular}{|c|c|c|c|c|c|c|}
\hline \multicolumn{7}{|c|}{$\begin{array}{l}\text { Appendix table } 6 \text {. Percent of state and federal inmates who were parents of minor } \\
\text { children, by criminal history and gender, } 2004\end{array}$} \\
\hline & \multicolumn{3}{|c|}{ Parents in state prison } & \multicolumn{3}{|c|}{ Parents in federal prison } \\
\hline & Total & Male & Female & Total & Male & Female \\
\hline All inmates & $51.9 \%$ & $51.2 \%$ & $61.7 \%$ & $62.9 \%$ & $63.4 \%$ & $55.9 \%$ \\
\hline \multicolumn{7}{|l|}{ Status at time of current arrest } \\
\hline None & $50.4 \%$ & $49.9 \%$ & $58.3 \%$ & $63.3 \%$ & $64.1 \%$ & $53.8 \%$ \\
\hline Status & 54.0 & 53.0 & 65.5 & 61.8 & 61.7 & 63.8 \\
\hline On parole & 50.0 & 49.6 & 59.6 & 59.5 & 60.0 & 46.1 \\
\hline On probation & 57.2 & 56.1 & 67.3 & 64.5 & 64.1 & 69.7 \\
\hline Escaped from custody & 43.6 & 40.9 & 66.5 & $\wedge$ & $\wedge$ & $\wedge$ \\
\hline \multicolumn{7}{|l|}{ Criminal history ${ }^{a}$} \\
\hline None & $48.0 \%$ & $47.0 \%$ & $57.9 \%$ & $57.4 \%$ & $58.0 \%$ & $53.0 \%$ \\
\hline Priors & 53.2 & 52.5 & 63.5 & 66.0 & 66.3 & 59.9 \\
\hline Violent recidivists $^{\mathrm{b}}$ & 52.3 & 51.9 & 63.6 & 62.6 & 62.7 & 59.1 \\
\hline Drug recidivists only & 61.9 & 62.4 & 58.7 & 70.3 & 71.3 & 54.5 \\
\hline Other recidivists ${ }^{\mathrm{C}}$ & 53.5 & 52.4 & 64.2 & 67.7 & 68.1 & 61.6 \\
\hline \multicolumn{7}{|l|}{ Number of prior incarcerations } \\
\hline 0 & $50.8 \%$ & $49.8 \%$ & $61.4 \%$ & $62.0 \%$ & $62.8 \%$ & $53.9 \%$ \\
\hline 1 & 53.2 & 52.5 & 63.9 & 60.8 & 61.0 & 56.4 \\
\hline $2-4$ & 53.1 & 52.7 & 60.6 & 68.8 & 69.0 & 61.0 \\
\hline $5-9$ & 50.6 & 50.2 & 60.5 & 62.0 & 61.6 & 76.2 \\
\hline 10 or more & 53.9 & 53.2 & 65.2 & 61.7 & 60.3 & 80.5 \\
\hline \multicolumn{7}{|c|}{$\begin{array}{l}\text { Note: See appendix table } 17 \text { for estimated total counts. } \\
{ }^{\wedge} \text { Estimate not reported. Sample size too small (10 or fewer) to pr } \\
{ }^{\mathrm{a}} \text { Includes prior probation, parole, and incarceration sentences. } \\
{ }^{b} \text { Recidivists with at least one current or past violent offense. } \\
{ }^{c} \text { Includes recidivists with unknown offense types. }\end{array}$} \\
\hline
\end{tabular}




\begin{tabular}{|c|c|c|c|}
\hline \multicolumn{4}{|c|}{$\begin{array}{l}\text { Appendix table 7. Parents in federal prison who reported living with their minor children } \\
\text { in the month before arrest or just prior to incarceration, by gender, } 2004\end{array}$} \\
\hline \multirow[b]{2}{*}{ Lived with their minor children } & \multicolumn{3}{|c|}{ Parents in federal prison } \\
\hline & Total & Male & Female \\
\hline In month before arrest & $48.1 \%$ & $46.4 \%$ & $72.8 \%$ \\
\hline In two-parent household & 27.2 & 27.6 & 20.7 \\
\hline In single-parent household & 20.9 & 18.8 & 52.1 \\
\hline Prior to incarceration & $52.2 \%$ & $50.5 \%$ & $78.3 \%$ \\
\hline Either in the month before arrest or just prior to incarceration & $56.4 \%$ & $54.7 \%$ & $80.9 \%$ \\
\hline Estimated number of parents in federal prison & 81,300 & 76,200 & 5,100 \\
\hline
\end{tabular}

\begin{tabular}{|c|c|c|c|c|c|c|}
\hline \multicolumn{7}{|c|}{ Appendix table 8. Daily care and living status of minor children of parents in state and federal prisons, by gender, 200} \\
\hline & \multicolumn{3}{|c|}{ Parents in state prison } & \multicolumn{3}{|c|}{ Parents in federal prison } \\
\hline & Total & Male & Female & Total & Male & Female \\
\hline Inmate lived with children just prior to incarceration & $43.8 \%$ & $42.4 \%$ & $60.6 \%$ & $52.2 \%$ & $50.5 \%$ & $78.3 \%$ \\
\hline Estimated number of parents & 636,300 & 585,200 & 51,100 & 81,300 & 76,200 & 5,100 \\
\hline \multicolumn{7}{|l|}{ Most of daily care of children provided by ${ }^{a}-$} \\
\hline Inmate who lived with children & $31.8 \%$ & $26.1 \%$ & $77.1 \%$ & $36.1 \%$ & $31.3 \%$ & $82.8 \%$ \\
\hline Inmate shared care with someone else & 58.3 & 63.3 & 18.1 & 54.9 & 59.0 & 14.5 \\
\hline Care was provided mostly by someone else & 9.9 & 10.5 & 4.7 & 9.0 & 9.7 & 2.7 \\
\hline Estimated number of parents & 278,900 & 248,100 & 30,800 & 42,500 & 38,600 & 3,900 \\
\hline Children currently living together & $61.9 \%$ & $62.3 \%$ & $59.0 \%$ & $60.7 \%$ & $61.0 \%$ & $57.9 \%$ \\
\hline Estimated number of parents & 188,300 & 167,400 & 20,900 & 29,400 & 26,800 & 2,600 \\
\hline
\end{tabular}




\begin{tabular}{|c|c|c|c|c|c|c|}
\hline & \multicolumn{3}{|c|}{ Parents in state prison } & \multicolumn{3}{|c|}{ Parents in federal prison } \\
\hline & Total & Male & Female & Total & Male & Female \\
\hline Parents who provided primary financial support & $54.0 \%$ & $54.1 \%$ & $51.9 \%$ & $67.2 \%$ & $67.1 \%$ & $68.5 \%$ \\
\hline $\begin{array}{l}\text { Employed in month before arrest } \\
\text { Sources of income }\end{array}$ & $80.3 \%$ & $81.5 \%$ & $66.4 \%$ & $77.0 \%$ & $77.6 \%$ & $67.7 \%$ \\
\hline Wages or salary & $75.9 \%$ & $77.1 \%$ & $60.7 \%$ & $73.0 \%$ & $73.4 \%$ & $67.5 \%$ \\
\hline Transfer payments & 11.7 & 9.6 & 36.1 & 8.4 & 7.4 & 23.7 \\
\hline Family/friends & 10.1 & 9.1 & 21.0 & 8.5 & 8.0 & 15.4 \\
\hline Child support/alimony payments & 1.0 & $\wedge$ & 9.3 & 0.6 & $\wedge$ & 7.5 \\
\hline Illegal sources & 24.1 & 24.3 & 21.2 & 35.7 & 36.3 & 26.8 \\
\hline Other & 2.9 & 2.9 & 3.3 & 3.6 & 3.7 & $\wedge$ \\
\hline \multicolumn{7}{|l|}{ Personal income in the month before current arrest } \\
\hline No income & $1.2 \%$ & $1.1 \%$ & $2.5 \%$ & $1.0 \%$ & $\wedge \%$ & $\wedge \%$ \\
\hline Less than $\$ 200$ & 2.1 & 2.1 & 3.3 & 2.2 & 2.2 & $\wedge$ \\
\hline$\$ 200-599$ & 13.1 & 12.3 & 23.8 & 11.1 & 10.5 & 19.4 \\
\hline$\$ 600-999$ & 13.8 & 13.3 & 19.8 & 12.2 & 11.9 & 16.9 \\
\hline$\$ 1,000-1,999$ & 33.0 & 33.4 & 28.3 & 27.5 & 27.5 & 27.3 \\
\hline$\$ 2,000-4,999$ & 23.6 & 24.4 & 14.0 & 22.5 & 22.8 & 17.0 \\
\hline$\$ 5,000$ or more & 13.1 & 13.5 & 8.3 & 23.5 & 24.1 & 14.8 \\
\hline Current caregiver of child receiving financial assistance & $34.7 \%$ & $34.3 \%$ & $39.2 \%$ & $29.1 \%$ & $28.6 \%$ & $35.4 \%$ \\
\hline Parents who did not provide primary financial support & $46.0 \%$ & $45.9 \%$ & $48.1 \%$ & $32.8 \%$ & $32.9 \%$ & $31.5 \%$ \\
\hline Employed in month before arrest & $68.1 \%$ & $70.1 \%$ & $47.3 \%$ & $66.4 \%$ & $67.5 \%$ & $49.1 \%$ \\
\hline \multicolumn{7}{|l|}{ Sources of income } \\
\hline Wages or salary & $63.5 \%$ & $65.5 \%$ & $42.7 \%$ & $60.4 \%$ & $61.0 \%$ & $50.8 \%$ \\
\hline Transfer payments & 10.0 & 9.0 & 20.9 & 8.0 & 7.5 & 15.4 \\
\hline Family/friends & 12.7 & 12.0 & 20.6 & 10.4 & 10.1 & 14.4 \\
\hline Child support/alimony payments & 0.4 & $\wedge$ & 4.8 & $\wedge$ & $\wedge$ & $\wedge$ \\
\hline Illegal sources & 30.0 & 30.0 & 30.4 & 37.6 & 38.1 & 29.9 \\
\hline Other & 2.0 & 2.1 & $\wedge$ & 3.9 & 3.8 & $\wedge$ \\
\hline \multicolumn{7}{|l|}{ Personal income in the month before current arrest } \\
\hline No income & $2.7 \%$ & $2.4 \%$ & $6.9 \%$ & $2.0 \%$ & $\wedge \%$ & $11.5 \%$ \\
\hline Less than $\$ 200$ & 3.7 & 3.4 & 7.2 & 4.8 & 4.8 & $\wedge$ \\
\hline$\$ 200-599$ & 17.4 & 16.7 & 25.0 & 17.4 & 17.3 & 18.7 \\
\hline$\$ 600-999$ & 16.3 & 16.2 & 18.2 & 13.4 & 13.6 & 11.1 \\
\hline$\$ 1,000-1,999$ & 29.5 & 30.1 & 22.6 & 25.9 & 26.0 & 24.7 \\
\hline$\$ 2,000-4,999$ & 19.4 & 20.0 & 12.1 & 15.7 & 16.0 & 12.4 \\
\hline$\$ 5,000$ or more & 11.0 & 11.2 & 8.0 & 20.7 & 20.9 & 17.4 \\
\hline Current caregiver of child receiving financial assistance & $29.2 \%$ & $29.1 \%$ & $30.6 \%$ & $22.1 \%$ & $22.0 \%$ & $23.7 \%$ \\
\hline Estimated number of parents & 636,300 & 585,200 & 51,100 & 81,300 & 76,200 & 5,100 \\
\hline
\end{tabular}

${ }^{\wedge}$ Estimate not reported. Sample size too small (10 or fewer) to provide reliable data. 


\begin{tabular}{|c|c|c|c|c|c|c|}
\hline \multirow[b]{2}{*}{ Frequency and type of contact with minor children } & \multicolumn{3}{|c|}{ Parents in state prison } & \multicolumn{3}{|c|}{ Parents in federal prison } \\
\hline & Total & Male & Female & Total & Male & Female \\
\hline \multicolumn{7}{|l|}{ Any type of contact } \\
\hline Daily or almost daily & $9.1 \%$ & $8.7 \%$ & $14.1 \%$ & $18.8 \%$ & $18.3 \%$ & $26.9 \%$ \\
\hline At least once a week & 30.8 & 29.8 & 41.6 & 46.1 & 45.9 & 48.2 \\
\hline At least once a month & 22.3 & 22.7 & 18.1 & 17.0 & 17.1 & 14.7 \\
\hline Less than once a month & 16.5 & 16.9 & 11.2 & 9.4 & 9.6 & 6.2 \\
\hline Never & 21.4 & 21.9 & 15.0 & 8.8 & 9.1 & 3.9 \\
\hline \multicolumn{7}{|l|}{ Telephone } \\
\hline Daily or almost daily & $5.3 \%$ & $5.0 \%$ & $8.6 \%$ & $16.9 \%$ & $16.5 \%$ & $23.4 \%$ \\
\hline At least once a week & 17.5 & 17.1 & 22.4 & 40.9 & 40.7 & 43.7 \\
\hline At least once a month & 15.6 & 15.6 & 15.7 & 17.2 & 17.2 & 16.9 \\
\hline Less than once a month & 15.0 & 15.3 & 12.4 & 10.1 & 10.2 & 7.4 \\
\hline Never & 46.6 & 47.1 & 40.9 & 14.9 & 15.4 & 8.5 \\
\hline \multicolumn{7}{|l|}{ Mail } \\
\hline Daily or almost daily & $4.5 \%$ & $4.3 \%$ & $6.9 \%$ & $4.2 \%$ & $4.0 \%$ & $7.7 \%$ \\
\hline At least once a week & 24.0 & 23.0 & 35.3 & 29.0 & 28.3 & 40.4 \\
\hline At least once a month & 23.2 & 23.3 & 22.5 & 31.0 & 31.2 & 28.2 \\
\hline Less than once a month & 17.9 & 18.3 & 13.0 & 19.8 & 20.2 & 12.9 \\
\hline Never & 30.4 & 31.1 & 22.3 & 16.0 & 16.3 & 10.7 \\
\hline \multicolumn{7}{|l|}{ Personal visits } \\
\hline Daily or almost daily & $0.6 \%$ & $0.6 \%$ & $\wedge \%$ & $\wedge \%$ & $\wedge \%$ & $\wedge \%$ \\
\hline At least once a week & 5.9 & 5.7 & 7.7 & 4.6 & 4.4 & 7.6 \\
\hline At least once a month & 12.5 & 12.3 & 14.6 & 14.7 & 14.7 & 15.5 \\
\hline Less than once a month & 22.5 & 22.7 & 19.7 & 35.6 & 35.9 & 31.5 \\
\hline Never & 58.5 & 58.6 & 57.7 & 44.7 & 44.7 & 44.6 \\
\hline Estimated number of parents & 636,300 & 585,200 & 51,100 & 81,300 & 76,200 & 5,100 \\
\hline
\end{tabular}

Note: The contact question included in the 2004 SISFCF asked about contact with any child, which could include children age 18 or older.

${ }^{\wedge}$ Estimate not reported. Sample size too small (10 or fewer) to provide reliable data.

\begin{tabular}{|c|c|c|c|c|c|c|}
\hline & \multicolumn{3}{|c|}{ Parents in state prison } & \multicolumn{3}{|c|}{ Parents in federal prison } \\
\hline & Total & Male & Female & Total & Male & Female \\
\hline \multicolumn{7}{|l|}{ While growing up, parent- } \\
\hline Ever received public assistance & $39.9 \%$ & $39.8 \%$ & $41.3 \%$ & $31.2 \%$ & $31.2 \%$ & $31.7 \%$ \\
\hline Ever lived in foster home, agency, or institution & $14.0 \%$ & $13.7 \%$ & $17.3 \%$ & 7.0 & 6.9 & 7.6 \\
\hline \multicolumn{7}{|l|}{ Lived most of the time with- } \\
\hline Both parents & $43.1 \%$ & $43.2 \%$ & $41.1 \%$ & $45.5 \%$ & $45.2 \%$ & $50.6 \%$ \\
\hline One parent & 43.5 & 43.7 & 42.0 & 41.2 & 41.6 & 34.3 \\
\hline Someone else* & 11.5 & 11.2 & 14.0 & 12.6 & 12.5 & 14.1 \\
\hline Foster home, agency, or institution & 1.9 & 1.8 & 3.0 & 0.7 & 0.7 & $\wedge$ \\
\hline $\begin{array}{l}\text { Parents or guardians of inmate ever abused } \\
\text { alcohol or drugs- }\end{array}$ & $33.7 \%$ & $32.9 \%$ & $43.0 \%$ & $27.2 \%$ & $27.0 \%$ & $31.4 \%$ \\
\hline Alcohol only & 19.6 & 19.3 & 23.6 & 19.2 & 19.4 & 17.3 \\
\hline Drugs only & 3.1 & 3.0 & 3.7 & 2.2 & 2.0 & 5.3 \\
\hline Both alcohol and drugs & 11.0 & 10.6 & 15.7 & 5.8 & 5.6 & 8.8 \\
\hline None & 66.3 & 67.1 & 57.0 & 72.8 & 73.0 & 68.6 \\
\hline Estimated number of parents & 636,300 & 585,200 & 51,100 & 81,300 & 76,200 & 5,100 \\
\hline
\end{tabular}

${ }^{\wedge}$ Estimate not reported. Sample size too small (10 or fewer) to provide reliable data.

*Includes grandparents, other relatives, friends, and others. 


\begin{tabular}{|c|c|c|c|c|c|c|}
\hline \multicolumn{7}{|c|}{$\begin{array}{l}\text { Appendix table } 12 \text {. Homelessness, } \mathrm{physical} / \mathrm{sexual} \text { abuse, medical/mental } \\
\text { abuse problems among state and federal inmates who were parents of mir } \\
\text { Parents in state prison }\end{array}$} \\
\hline & Total & Male & Female & Total & Male & Female \\
\hline Homelessness in year before arrest & $8.9 \%$ & $8.3 \%$ & $15.9 \%$ & $3.9 \%$ & $3.9 \%$ & $4.4 \%$ \\
\hline $\begin{array}{l}\text { Ever physical/sexual abuse } \\
\text { Physically abused } \\
\text { Sexually abused }\end{array}$ & $\begin{array}{l}19.9 \% \\
16.6 \\
8.7\end{array}$ & $\begin{array}{l}16.0 \% \\
13.4 \\
5.7\end{array}$ & $\begin{array}{l}64.4 \% \\
52.8 \\
43.3\end{array}$ & $\begin{array}{l}10.8 \% \\
9.1 \\
3.7\end{array}$ & $\begin{array}{l}8.0 \% \\
6.6 \\
2.0\end{array}$ & $\begin{array}{l}53.6 \% \\
46.8 \\
29.0\end{array}$ \\
\hline Current medical problem & $40.6 \%$ & $39.6 \%$ & $52.8 \%$ & $35.6 \%$ & $35.0 \%$ & $44.8 \%$ \\
\hline $\begin{array}{l}\text { Mental health problem } \\
\text { Any mental health problem } \\
\text { Recent history of mental health problem } \\
\text { Symptoms of mental health disorders }\end{array}$ & $\begin{array}{l}56.5 \% \\
22.6 \\
50.1\end{array}$ & $\begin{array}{l}55.0 \% \\
20.4 \\
49.0\end{array}$ & $\begin{array}{l}73.8 \% \\
48.8 \\
63.2\end{array}$ & $\begin{array}{l}42.6 \% \\
11.9 \\
38.6\end{array}$ & $\begin{array}{l}41.3 \% \\
10.3 \\
37.7\end{array}$ & $\begin{array}{l}62.1 \% \\
35.1 \\
52.6\end{array}$ \\
\hline $\begin{array}{l}\text { Substance dependence/abuse } \\
\text { Any alcohol or drugs } \\
\text { Alcohol only } \\
\text { Drugs only }\end{array}$ & $\begin{array}{l}67.4 \% \\
44.4 \\
55.4\end{array}$ & $\begin{array}{l}67.1 \% \\
45.0 \\
54.8\end{array}$ & $\begin{array}{l}70.1 \% \\
37.6 \\
62.8\end{array}$ & $\begin{array}{l}56.4 \% \\
36.7 \\
45.7\end{array}$ & $\begin{array}{l}56.7 \% \\
37.0 \\
45.9\end{array}$ & $\begin{array}{l}51.3 \% \\
32.5 \\
43.4\end{array}$ \\
\hline Estimated number of parents & 636,300 & 585,200 & 51,100 & 81,300 & 76,200 & 5,100 \\
\hline
\end{tabular}

\begin{tabular}{|c|c|c|c|c|c|c|}
\hline \multicolumn{7}{|c|}{$\begin{array}{l}\text { Appendix table 13. Alcohol or drug and mental health treatment history of inmates in state and federal prisons who were } \\
\text { parents of minor children and who had an alcohol or drug or mental health problem, by gender, } 2004\end{array}$} \\
\hline & \multicolumn{3}{|c|}{ Parents in state prison } & \multicolumn{3}{|c|}{ Parents in federal prison } \\
\hline \multicolumn{7}{|l|}{ Alcohol or drug treatment ${ }^{\mathrm{a}}$} \\
\hline Ever any treatment or programs & $69.8 \%$ & $69.3 \%$ & $75.6 \%$ & $69.1 \%$ & $68.7 \%$ & $75.9 \%$ \\
\hline Received treatment since admission & $42.9 \%$ & $42.4 \%$ & $48.0 \%$ & $45.9 \%$ & $45.4 \%$ & $54.1 \%$ \\
\hline Any treatment & 15.2 & 14.5 & 22.1 & 15.8 & 15.5 & 21.0 \\
\hline Residential facility or unit & 10.1 & 9.7 & 14.3 & 8.9 & 8.5 & 16.8 \\
\hline Counseling by a professional & 6.4 & 6.1 & 9.5 & 7.2 & 7.2 & 7.4 \\
\hline Detoxification unit & 0.8 & 0.7 & 2.1 & $\wedge$ & $\wedge$ & $\wedge$ \\
\hline Maintenance drug & 0.2 & $\wedge$ & 0.8 & $\wedge$ & $\wedge$ & $\wedge$ \\
\hline Estimated number of parents who had an alcohol or drug problem & 428,600 & 392,800 & 35,800 & 45,900 & 43,300 & 2,600 \\
\hline \multicolumn{7}{|l|}{ Mental health treatment ${ }^{\mathrm{b}}$} \\
\hline Used prescribed medications & 37.8 & 34.8 & 63.0 & 24.3 & 21.6 & 50.2 \\
\hline Had professional mental health therapy & 33.0 & 30.5 & 54.3 & 22.8 & 20.7 & 44.4 \\
\hline Received treatment since admission & $30.9 \%$ & $28.3 \%$ & $52.9 \%$ & $21.2 \%$ & $19.0 \%$ & $43.3 \%$ \\
\hline Had overnight hospital stay & 4.7 & 4.7 & 4.4 & 2.1 & 1.9 & 4.0 \\
\hline Used prescribed medications & 24.5 & 22.3 & 43.6 & 17.0 & 15.3 & 34.0 \\
\hline Had professional mental health therapy & 20.5 & 18.7 & 36.2 & 13.3 & 11.8 & 27.7 \\
\hline Estimated number of parents who had a mental health problem & 359,200 & 321,600 & 37,600 & 34,700 & 31,500 & 3,200 \\
\hline
\end{tabular}

${ }^{\wedge}$ Estimate not reported. Sample size too small (10 or fewer) to provide reliable data.

${ }^{a}$ Based on inmate parents who had an alcohol or drug problem.

${ }^{b}$ Based on inmate parents who had a mental health problem. 


\begin{tabular}{|c|c|c|c|c|c|c|}
\hline \multicolumn{7}{|c|}{$\begin{array}{l}\text { Appendix table } 14 \text {. Work assignments, program participation, and education among state and federal inmates } \\
\text { who were parents of minor children, by gender, } 2004\end{array}$} \\
\hline & \multicolumn{3}{|c|}{ Parents in state prison } & \multicolumn{3}{|c|}{ Parents in federal prison } \\
\hline & Total & Male & Female & Total & Male & Female \\
\hline Work assignments ${ }^{a}$ & $66.8 \%$ & $66.5 \%$ & $70.2 \%$ & $93.0 \%$ & $93.0 \%$ & $93.6 \%$ \\
\hline Self-help or improvement classes since admission & $57.2 \%$ & $56.5 \%$ & $64.9 \%$ & $72.8 \%$ & $72.2 \%$ & $81.0 \%$ \\
\hline Parenting or childrearing classes & 11.9 & 10.6 & 27.0 & 25.9 & 24.8 & 42.1 \\
\hline Employment programs & 30.4 & 30.4 & 31.1 & 37.4 & 37.0 & 43.9 \\
\hline Vocational or job-training program & 26.5 & 26.6 & 25.5 & 32.6 & 32.4 & 35.4 \\
\hline Employment counseling & 9.4 & 9.1 & 12.1 & 11.8 & 11.4 & 18.3 \\
\hline Education programs ${ }^{\mathrm{b}}$ & 30.3 & 30.0 & 32.7 & 46.9 & 47.0 & 45.4 \\
\hline Other pre-release programs ${ }^{c}$ & 31.2 & 30.5 & 39.7 & 38.1 & 37.3 & 48.6 \\
\hline \multicolumn{7}{|l|}{ Had GED or high school diploma upon admission } \\
\hline Percent & $62.4 \%$ & $62.4 \%$ & $62.2 \%$ & $70.7 \%$ & $70.9 \%$ & $68.6 \%$ \\
\hline Estimated number & 636,300 & 585,200 & 51,100 & 81,300 & 76,200 & 5,100 \\
\hline \multicolumn{7}{|l|}{ Completed GED since admission ${ }^{d}$} \\
\hline Percent & $2.0 \%$ & $2.0 \%$ & $\wedge$ & $\wedge$ & $\wedge$ & $\wedge$ \\
\hline Estimated number & 81,000 & 73,700 & $\wedge$ & $\wedge$ & $\wedge$ & $\wedge$ \\
\hline \multicolumn{7}{|c|}{ ^Estimate not reported. Sample size too small (10 or fewer) to provide reliable data. } \\
\hline \multicolumn{7}{|c|}{ ancludes work assignments both inside and outside the prison. } \\
\hline \multicolumn{7}{|c|}{$\begin{array}{l}\text { bExcludes vocational training. Includes basic classes up to 9th grade, high school classes to get a diploma, or GED, } \\
\text { college level classes, or English as a second language. }\end{array}$} \\
\hline \multicolumn{7}{|c|}{$\begin{array}{l}\text { cIncludes inmate assistance/counseling groups, inmate self-help/personal improvement groups, including parent } \\
\text { awareness groups, life skills/community adjustment classes, and other pre-release programs. }\end{array}$} \\
\hline $\begin{array}{l}\text { d Based on inmate parents who at the time of admissior } \\
\text { did not have a GED. }\end{array}$ & n on their $\mathrm{cu}$ & urrent senten & had not c & ted high sch & & \\
\hline
\end{tabular}

\begin{tabular}{|c|c|c|c|c|c|c|}
\hline \multicolumn{7}{|c|}{$\begin{array}{l}\text { Appendix table } 15 \text {. Time served since admission and time to be s } \\
\text { state and federal inmates who were parents of minor children, by }\end{array}$} \\
\hline & \multicolumn{3}{|c|}{ Parents in state prison } & \multicolumn{3}{|c|}{ Parents in federal prison } \\
\hline & Total & Male & Female & Total & Male & Female \\
\hline \multicolumn{7}{|l|}{ Time served since admission ${ }^{a}$} \\
\hline Less than 6 months & $9.4 \%$ & $8.7 \%$ & $17.7 \%$ & $4.6 \%$ & $4.5 \%$ & $7.0 \%$ \\
\hline 6-11 months & 13.1 & 12.5 & 19.8 & 7.5 & 7.1 & 14.1 \\
\hline $12-59$ months & 51.9 & 52.1 & 49.9 & 56.2 & 55.9 & 60.5 \\
\hline $60+$ months & 25.5 & 26.7 & 12.6 & 31.6 & 32.6 & 18.4 \\
\hline \multicolumn{7}{|c|}{ Time left to be served on current sentence ${ }^{b}$} \\
\hline Less than 6 months & $26.7 \%$ & $25.4 \%$ & $41.1 \%$ & $14.2 \%$ & $13.3 \%$ & $28.1 \%$ \\
\hline $6-11$ months & 15.4 & 14.9 & 20.4 & 9.9 & 9.3 & 17.2 \\
\hline $12-59$ months & 37.9 & 38.7 & 28.9 & 40.3 & 40.3 & 40.8 \\
\hline $60+$ months & 17.8 & 18.6 & 8.2 & 34.1 & 35.5 & 13.6 \\
\hline No release expected & 2.3 & 2.4 & 1.1 & 1.5 & 1.6 & $\wedge$ \\
\hline Estimated number of parents & 636,300 & 585,200 & 51,100 & 81,300 & 76,200 & 5,100 \\
\hline
\end{tabular}




\begin{tabular}{|c|c|c|c|c|c|c|}
\hline \multicolumn{7}{|c|}{$\begin{array}{l}\text { Appendix table 16. Estimated number of inmates, by selected characteristics and } \\
\text { gender, } 2004\end{array}$} \\
\hline & \multicolumn{3}{|c|}{ Estimated number of state inmates } & \multicolumn{3}{|c|}{ Estimated number of federal inmates } \\
\hline & Total & Male & Female & Total & Male & Female \\
\hline Total & $1,226,200$ & $1,143,400$ & 82,800 & 129,300 & 120,200 & 9,100 \\
\hline \multicolumn{7}{|l|}{ Race/Hispanic origin } \\
\hline White, non-Hispanic & 431,500 & 394,000 & 37,500 & 33,600 & 30,900 & 2,700 \\
\hline Black, non-Hispanic & 496,900 & 469,200 & 27,700 & 56,000 & 53,200 & 2,900 \\
\hline Hispanic & 222,700 & 211,100 & 11,600 & 32,400 & 29,700 & 2,700 \\
\hline Other race* & 75,100 & 69,100 & 5,900 & 7,200 & 6,400 & 800 \\
\hline \multicolumn{7}{|l|}{ Age } \\
\hline 24 or younger & 212,400 & 200,900 & 11,400 & 11,600 & 10,800 & 800 \\
\hline $25-34$ & 405,500 & 379,800 & 25,700 & 49,700 & 46,700 & 2,900 \\
\hline $35-44$ & 373,700 & 341,800 & 31,900 & 37,300 & 34,500 & 2,800 \\
\hline $45-54$ & 172,700 & 161,100 & 11,600 & 22,200 & 20,600 & 1,700 \\
\hline 55 or older & 61,900 & 59,700 & 2,200 & 8,500 & 7,600 & 900 \\
\hline \multicolumn{7}{|l|}{ Marital status } \\
\hline Married & 201,600 & 186,600 & 15,100 & 33,600 & 31,200 & 2,400 \\
\hline Widowed & 24,100 & 20,100 & 4,000 & 1,500 & 1,100 & 400 \\
\hline Divorced & 241,600 & 222,400 & 19,200 & 26,200 & 24,200 & 2,000 \\
\hline Separated & 62,600 & 55,100 & 7,500 & 6,600 & 5,900 & 700 \\
\hline Never married & 696,200 & 659,200 & 37,000 & 61,400 & 57,900 & 3,500 \\
\hline \multicolumn{7}{|l|}{ Education completed } \\
\hline 8th grade or less & 150,800 & 141,100 & 9,700 & 14,000 & 13,000 & 1,000 \\
\hline Some high school & 298,100 & 277,300 & 20,800 & 20,700 & 19,100 & 1,600 \\
\hline GED & 367,000 & 347,000 & 20,000 & 37,200 & 35,300 & 1,900 \\
\hline High school graduate & 265,400 & 247,100 & 18,300 & 31,200 & 29,000 & 2,100 \\
\hline Some college or more & 144,900 & 130,900 & 14,000 & 26,200 & 23,800 & 2,500 \\
\hline \multicolumn{7}{|l|}{ U.S. Citizenship } \\
\hline Citizen & $1,163,000$ & $1,081,600$ & 81,400 & 108,100 & 100,400 & 7,700 \\
\hline Non-citizen & 63,200 & 61,800 & 1,400 & 21,200 & 19,800 & 1,300 \\
\hline $\begin{array}{l}\text { Note: Estimates may not sun } \\
\text { *Includes American Indians, } \\
\text { Islanders, and persons ident }\end{array}$ & $\begin{array}{l}\text { Im to totals due } \\
\text {, Alaska Nativ } \\
\text { tifying two or } r\end{array}$ & $\begin{array}{l}\text { e to roundir } \\
\text { es, Asians, } \\
\text { more races }\end{array}$ & ative $\mathrm{Ha}$ & Ins, other $\mathrm{P}$ & & \\
\hline
\end{tabular}




\begin{tabular}{|c|c|c|c|c|c|c|}
\hline \multicolumn{7}{|c|}{ Appendix table 17. Estimated number of inmates, by offense, criminal history, and gender, 2004} \\
\hline & \multicolumn{3}{|c|}{ Estimated number of state inmates } & \multicolumn{3}{|c|}{ Estimated number of federal inmates } \\
\hline & Total & Male & Female & Total & Male & Female \\
\hline Total & $1,226,200$ & $1,143,400$ & 82,800 & 129,300 & 120,200 & 9,100 \\
\hline \multicolumn{7}{|l|}{ Offense } \\
\hline Violent & 587,200 & 562,700 & 24,500 & 18,900 & 18,200 & 700 \\
\hline Homicide ${ }^{\mathrm{a}}$ & 148,800 & 139,400 & 9,300 & 3,100 & 3,000 & 100 \\
\hline Sexual assault ${ }^{b}$ & 131,400 & 130,200 & 1,300 & 1,100 & 1,100 & $\wedge$ \\
\hline Robbery & 155,100 & 149,800 & 5,400 & 11,000 & 10,600 & 400 \\
\hline Assault & 124,500 & 118,100 & 6,400 & 2,600 & 2,500 & 100 \\
\hline Property & 229,900 & 206,200 & 23,700 & 8,400 & 7,100 & 1,400 \\
\hline Burglary & 100,200 & 97,000 & 3,200 & 600 & 600 & $\wedge$ \\
\hline Larceny & 47,600 & 40,800 & 6,900 & 600 & 500 & 100 \\
\hline Motor vehicle theft & 20,800 & 19,800 & 1,000 & 400 & 400 & $\wedge$ \\
\hline Fraud & 35,100 & 24,700 & 10,400 & 6,000 & 4,900 & 1,200 \\
\hline Drug & 261,500 & 235,900 & 25,500 & 71,400 & 66,000 & 5,500 \\
\hline Possession & 73,000 & 64,300 & 8,700 & 3,800 & 3,600 & 200 \\
\hline Trafficking & 181,400 & 166,100 & 15,300 & 65,200 & 60,300 & 5,000 \\
\hline Public-order & 145,500 & 136,700 & 8,800 & 26,500 & 25,400 & 1,000 \\
\hline Weapons & 30,500 & 29,900 & 600 & 14,200 & 14,000 & 200 \\
\hline DWI & 32,300 & 30,600 & 1,700 & 300 & 300 & $\wedge$ \\
\hline \multicolumn{7}{|l|}{ Status at time of arrest } \\
\hline None & 698,400 & 654,200 & 44,200 & 94,600 & 87,400 & 7,200 \\
\hline Status & 527,800 & 489,200 & 38,600 & 34,700 & 32,800 & 1,900 \\
\hline On parole & 229,100 & 220,000 & 9,100 & 16,000 & 15,500 & 500 \\
\hline On probation & 293,800 & 264,800 & 29,000 & 18,200 & 16,800 & 1,300 \\
\hline Escaped from custody & 4,900 & 4,400 & 500 & 500 & 500 & $\wedge$ \\
\hline \multicolumn{7}{|l|}{ Criminal history } \\
\hline None & 288,700 & 261,300 & 27,400 & 45,600 & 40,500 & 5,100 \\
\hline Priors & 937,500 & 882,000 & 55,400 & 83,700 & 79,700 & 4,000 \\
\hline Violent recidivists ${ }^{\mathrm{C}}$ & 536,700 & 518,200 & 18,500 & 32,800 & 32,000 & 800 \\
\hline Drug recidivists only & 42,200 & 37,400 & 4,800 & 10,900 & 10,200 & 700 \\
\hline Other recidivist $^{d}$ & 358,600 & 326,500 & 32,100 & 40,000 & 37,500 & 2,500 \\
\hline \multicolumn{7}{|l|}{ Number of prior incarcerations } \\
\hline 0 & 561,400 & 512,900 & 48,500 & 71,800 & 64,900 & 6,900 \\
\hline 1 & 267,900 & 252,100 & 15,800 & 27,300 & 26,100 & 1,200 \\
\hline $2-4$ & 250,500 & 238,600 & 11,800 & 21,700 & 21,100 & 600 \\
\hline $5-9$ & 101,600 & 97,400 & 4,100 & 6,200 & 6,000 & 200 \\
\hline 10 or more & 44,800 & 42,300 & 2,500 & 2,300 & 2,100 & 200 \\
\hline \multicolumn{7}{|c|}{$\begin{array}{l}\text { Note: Estimates may not sum to totals due to rounding. } \\
\wedge \text { Based on a number of cases which rounded to less than } 100 \text {. }\end{array}$} \\
\hline \multicolumn{7}{|c|}{ aIncludes murder and manslaughter. } \\
\hline \multicolumn{7}{|c|}{ b Includes rape and other sexual assault. } \\
\hline \multicolumn{7}{|c|}{${ }^{\mathrm{C}}$ Recidivists with at least one current or past violent offense. } \\
\hline dIncludes recidivists with unkn & offense type & & & & & \\
\hline
\end{tabular}




\begin{tabular}{|c|c|c|c|}
\hline \multicolumn{4}{|c|}{$\begin{array}{l}\text { Appendix table 18. Estimated number of parents in state prison, by } \\
\text { selected characteristics and gender, } 2004\end{array}$} \\
\hline & \multicolumn{3}{|c|}{ Parents in state prison } \\
\hline & Total & Male & Female \\
\hline All parents in state prison & 636,300 & 585,200 & 51,100 \\
\hline \multicolumn{4}{|l|}{ Lived with minor children* } \\
\hline Yes & 305,000 & 272,200 & 32,800 \\
\hline No & 331,300 & 313,000 & 18,300 \\
\hline \multicolumn{4}{|l|}{ Time expected until release } \\
\hline Less than 6 months & 169,800 & 148,700 & 21,200 \\
\hline $6-11$ months & 97,800 & 87,400 & 10,400 \\
\hline $12-59$ months & 241,200 & 226,300 & 14,800 \\
\hline 60 or more months & 113,000 & 108,800 & 4,200 \\
\hline No release expected & 14,500 & 14,000 & 500 \\
\hline
\end{tabular}




\begin{tabular}{|c|c|c|c|c|c|c|}
\hline \multirow{2}{*}{$\begin{array}{l}\text { Appendix table 19. Standarc } \\
\text { Base of the estimate and gender }\end{array}$} & \multicolumn{6}{|c|}{ Estimated percentages } \\
\hline & 98 or 2 & 90 or 10 & 80 or 20 & 70 or 30 & 60 or 40 & 50 \\
\hline \multicolumn{7}{|l|}{1,500} \\
\hline All inmates & 5.83 & 12.50 & 16.67 & 19.09 & 20.41 & 20.83 \\
\hline Male & 5.53 & 11.85 & 15.80 & 18.10 & 19.35 & 19.75 \\
\hline Female & 2.45 & 5.25 & 6.99 & 8.01 & 8.57 & 8.74 \\
\hline \multicolumn{7}{|l|}{2,000} \\
\hline All inmates & 5.05 & 10.83 & 14.43 & 16.54 & 17.68 & 18.04 \\
\hline Male & 4.79 & 10.26 & 13.69 & 15.68 & 16.76 & 17.11 \\
\hline Female & 2.12 & 4.54 & 6.06 & 6.94 & 7.42 & 7.57 \\
\hline \multicolumn{7}{|l|}{2,500} \\
\hline All inmates & 4.52 & 9.68 & 12.91 & 14.79 & 15.81 & 16.14 \\
\hline Male & 4.28 & 9.18 & 12.24 & 14.02 & 14.99 & 15.30 \\
\hline Female & 1.90 & 4.06 & 5.42 & 6.21 & 6.64 & 6.77 \\
\hline \multicolumn{7}{|l|}{5,000} \\
\hline All inmates & 3.20 & 6.85 & 9.13 & 10.46 & 11.18 & 11.41 \\
\hline Male & 3.03 & 6.49 & 8.66 & 9.92 & 10.60 & 10.82 \\
\hline Female & 1.34 & 2.87 & 3.83 & 4.39 & 4.69 & 4.79 \\
\hline \multicolumn{7}{|l|}{10,000} \\
\hline All inmates & 2.26 & 4.84 & 6.46 & 7.40 & 7.91 & 8.07 \\
\hline Male & 2.14 & 4.59 & 6.12 & 7.01 & 7.50 & 7.65 \\
\hline Female & 0.95 & 2.03 & 2.71 & 3.10 & 3.32 & 3.39 \\
\hline \multicolumn{7}{|l|}{20,000} \\
\hline All inmates & 1.60 & 3.42 & 4.56 & 5.23 & 5.59 & 5.71 \\
\hline Male & 1.51 & 3.25 & 4.33 & 4.96 & 5.30 & 5.41 \\
\hline Female & 0.67 & 1.44 & 1.92 & 2.19 & 2.35 & 2.39 \\
\hline \multicolumn{7}{|l|}{30,000} \\
\hline All inmates & 1.30 & 2.80 & 3.73 & 4.27 & 4.56 & 4.66 \\
\hline Male & 1.24 & 2.65 & 3.53 & 4.05 & 4.33 & 4.42 \\
\hline Female & 0.55 & 1.17 & 1.56 & 1.79 & 1.92 & 1.96 \\
\hline \multicolumn{7}{|l|}{50,000} \\
\hline All inmates & 1.01 & 2.17 & 2.89 & 3.31 & 3.54 & 3.61 \\
\hline Male & 0.96 & 2.05 & 2.74 & 3.14 & 3.35 & 3.42 \\
\hline Female & 0.42 & 0.91 & 1.21 & 1.39 & 1.48 & 1.51 \\
\hline \multicolumn{7}{|l|}{82,794} \\
\hline All inmates & 0.79 & 1.68 & 2.24 & 2.57 & 2.75 & 2.80 \\
\hline Male & 0.74 & 1.60 & 2.13 & 2.44 & 2.61 & 2.66 \\
\hline Female* & 0.33 & 0.71 & 0.94 & 1.08 & 1.15 & 1.18 \\
\hline \multicolumn{7}{|l|}{100,000} \\
\hline All inmates & 0.71 & 1.53 & 2.04 & 2.34 & 2.50 & 2.55 \\
\hline Male & 0.68 & 1.45 & 1.94 & 2.22 & 2.37 & 2.42 \\
\hline \multicolumn{7}{|l|}{200,000} \\
\hline All inmates & 0.51 & 1.08 & 1.44 & 1.65 & 1.77 & 1.80 \\
\hline Male & 0.48 & 1.03 & 1.37 & 1.57 & 1.68 & 1.71 \\
\hline \multicolumn{7}{|l|}{400,000} \\
\hline All inmates & 0.36 & 0.77 & 1.02 & 1.17 & 1.25 & 1.28 \\
\hline Male & 0.34 & 0.73 & 0.97 & 1.11 & 1.19 & 1.21 \\
\hline \multicolumn{7}{|l|}{600,000} \\
\hline All inmates & 0.29 & 0.63 & 0.83 & 0.95 & 1.02 & 1.04 \\
\hline Male & 0.28 & 0.59 & 0.79 & 0.91 & 0.97 & 0.99 \\
\hline \multicolumn{7}{|l|}{800,000} \\
\hline All inmates & 0.25 & 0.54 & 0.72 & 0.83 & 0.88 & 0.90 \\
\hline Male & 0.24 & 0.51 & 0.68 & 0.78 & 0.84 & 0.86 \\
\hline \multicolumn{7}{|l|}{$1,143,377$} \\
\hline All inmates & 0.21 & 0.45 & 0.60 & 0.69 & 0.74 & 0.75 \\
\hline Male* & 0.20 & 0.43 & 0.57 & 0.66 & 0.70 & 0.72 \\
\hline $1,226,171$ & & & & & & \\
\hline All inmates* & 0.20 & 0.44 & 0.58 & 0.67 & 0.71 & 0.73 \\
\hline
\end{tabular}




\begin{tabular}{|c|c|c|c|c|c|c|}
\hline \multirow{2}{*}{$\begin{array}{l}\text { Appendix table 20. Standard } \\
\text { Base of the estimate and gender }\end{array}$} & \multicolumn{6}{|c|}{ Estimated percentages } \\
\hline & 98 or 2 & 90 or 10 & 80 or 20 & 70 or 30 & 60 or 40 & 50 \\
\hline \multicolumn{7}{|l|}{500} \\
\hline All inmates & 6.33 & 13.56 & 18.08 & 20.71 & 22.14 & 22.60 \\
\hline Male & 6.01 & 12.89 & 17.19 & 19.69 & 21.05 & 21.48 \\
\hline Female & 2.78 & 5.96 & 7.94 & 9.10 & 9.73 & 9.93 \\
\hline \multicolumn{7}{|l|}{1,000} \\
\hline All inmates & 4.47 & 9.59 & 12.79 & 14.65 & 15.66 & 15.98 \\
\hline Male & 4.25 & 9.11 & 12.15 & 13.92 & 14.88 & 15.19 \\
\hline Female & 1.97 & 4.21 & 5.62 & 6.43 & 6.88 & 7.02 \\
\hline \multicolumn{7}{|l|}{2,000} \\
\hline All inmates & 3.16 & 6.78 & 9.04 & 10.36 & 11.07 & 11.30 \\
\hline Male & 3.01 & 6.44 & 8.59 & 9.84 & 10.52 & 10.74 \\
\hline Female & 1.39 & 2.98 & 3.97 & 4.55 & 4.86 & 4.96 \\
\hline \multicolumn{7}{|l|}{5,000} \\
\hline All inmates & 2.00 & 4.29 & 5.72 & 6.55 & 7.00 & 7.15 \\
\hline Male & 1.90 & 4.08 & 5.43 & 6.23 & 6.66 & 6.79 \\
\hline Female & 0.88 & 1.88 & 2.51 & 2.88 & 3.08 & 3.14 \\
\hline \multicolumn{7}{|l|}{7,500} \\
\hline All inmates & 1.63 & 3.50 & 4.67 & 5.35 & 5.72 & 5.84 \\
\hline Male & 1.55 & 3.33 & 4.44 & 5.08 & 5.43 & 5.55 \\
\hline Female & 0.72 & 1.54 & 2.05 & 2.35 & 2.51 & 2.56 \\
\hline \multicolumn{7}{|l|}{9,063} \\
\hline All inmates & 1.49 & 3.19 & 4.25 & 4.87 & 5.20 & 5.31 \\
\hline Male & 1.41 & 3.03 & 4.04 & 4.62 & 4.94 & 5.05 \\
\hline Female* & 0.65 & 1.40 & 1.87 & 2.14 & 2.28 & 2.33 \\
\hline \multicolumn{7}{|l|}{12,500} \\
\hline All inmates & 1.27 & 2.71 & 3.62 & 4.14 & 4.43 & 4.52 \\
\hline Male & 1.20 & 2.58 & 3.44 & 3.94 & 4.21 & 4.30 \\
\hline \multicolumn{7}{|l|}{15,000} \\
\hline All inmates & 1.16 & 2.48 & 3.30 & 3.78 & 4.04 & 4.13 \\
\hline Male & 1.10 & 2.35 & 3.14 & 3.59 & 3.84 & 3.92 \\
\hline \multicolumn{7}{|l|}{25,000} \\
\hline All inmates & 0.89 & 1.92 & 2.56 & 2.93 & 3.13 & 3.20 \\
\hline Male & 0.85 & 1.82 & 2.43 & 2.78 & 2.98 & 3.04 \\
\hline \multicolumn{7}{|l|}{40,000} \\
\hline All inmates & 0.71 & 1.52 & 2.02 & 2.32 & 2.48 & 2.53 \\
\hline Male & 0.67 & 1.44 & 1.92 & 2.20 & 2.35 & 2.40 \\
\hline \multicolumn{7}{|l|}{50,000} \\
\hline All inmates & 0.63 & 1.36 & 1.81 & 2.07 & 2.21 & 2.26 \\
\hline Male & 0.60 & 1.29 & 1.72 & 1.97 & 2.10 & 2.15 \\
\hline \multicolumn{7}{|l|}{75,000} \\
\hline All inmates & 0.52 & 1.11 & 1.48 & 1.69 & 1.81 & 1.85 \\
\hline Male & 0.49 & 1.05 & 1.40 & 1.61 & 1.72 & 1.75 \\
\hline \multicolumn{7}{|l|}{100,000} \\
\hline All inmates & 0.45 & 0.96 & 1.28 & 1.46 & 1.57 & 1.60 \\
\hline Male & 0.43 & 0.91 & 1.22 & 1.39 & 1.49 & 1.52 \\
\hline \multicolumn{7}{|l|}{120,237} \\
\hline All inmates & 0.41 & 0.87 & 1.17 & 1.34 & 1.43 & 1.46 \\
\hline Male* & 0.39 & 0.83 & 1.11 & 1.27 & 1.36 & 1.39 \\
\hline \multicolumn{7}{|l|}{129,300} \\
\hline All inmates* & 0.39 & 0.84 & 1.12 & 1.29 & 1.38 & 1.41 \\
\hline \multicolumn{7}{|c|}{$\begin{array}{l}\text { Note: The reliability of an estimated percentage depends on the size and its base. Each standard error when multiplied by } 1.96 \\
\text { provides a 95-percent confidence interval around an estimated percentage. To calculate the difference between two estimated } \\
\text { percentages, take the square root of the sum of each squared standard error for the percentages being compared. } \\
\text { * The total number of male, female, and all federal prisoners in } 2004 \text {. }\end{array}$} \\
\hline
\end{tabular}

